\title{
Tam Sayıların Öğretim Sürecinin Öğretmenlerin Model Kullanımları Üzerinden Analizi*
}

\author{
Kiraz Koç Şanlı** , Cemalettin Işsk **** \\ Makale Geliş Tarihi: 30/01/2019 \\ Makale Kabul Tarihi: 14/05/2019 \\ DOI: $10.35675 /$ befdergi.519552
}

$\ddot{O} z$

Bu araştırmada tam sayllar ve tam sayllarla işlemler konularının ögretim sürecinin ögretmenlerin matematiksel model kullanımlart ve model tercihleri üzerinden analiz edilmesi amaçlanmıştır. Nitel araştırma yaklaşımlarından durum (örnek olay) çalışmasının kullanıldı̆̆ bu araştırma, 2016-2017 ĕgitim-ögretim yllında Niğde ilinde görev yapan 5 farklı matematik öğretmeni ile gerçekleştirilmiştir. Araştırmada öğretmenlere yönelik veriler "Ders Gözlem Formu" kullanılarak toplanmıştır. Araştırmaya gönüllü olarak katılan öğretmenlerin tam sayılar ve tam sayılarla işlemler konularını işledikleri 6. ve 7. sınıf düzeyindeki tüm dersleri video ile kayıt altına alınmıştır. Video kayıtları ve gözlem formlarından faydalanarak ögretim süreci, modellerin kullanımı açısından analiz edilmiştir. Bu araştırmada verilerin analizinde betimsel analiz yöntemi kullanılmıştır. Araştırmadan elde edilen verilerden, ögretmenlerin tam sayılar konusunun öğretim sürecinde programda önerilen ve ders kitabında yer alan modelleri düzenli olarak kullanmadıkları, 6. sınıf düzeyinde 7. sınıf düzeyine oranla daha çok model kullanmayı tercih ettikleri gözlenmiştir.

Anahtar Kelimeler: Matematiksel model, modelleme, tam sayllar, tam sayllarla işlemler.

\section{Analysis of Teachers' Usage of Models at Teaching of Integers}

\begin{abstract}
In this study, it was aimed to analyze teachers' usage and preference of mathematical models at their teaching of integers and operations with integers. This study was done as a case study, which is a type of qualitative research, was done with 5 different mathematics teachers working in Niğde province during 2016-2017 academic year. Data about teacher related issues were gathered through "Lesson Observation Form". All the lessons about integers and operations with integers in 6th and 7th grade levels mathematics classes were videotaped in volunteer teachers' classrooms. With the help of video records and lesson observation form, teaching processes were analyzed for the usage of models. In this study, descriptive analysis technique was used for analyzing data gathered. Data gathered indicated that teachers didn't regularly use the models presented in the curriculum and textbooks, and besides, they preferred using more models in 6th grade courses than 7 th grade courses.
\end{abstract}

\footnotetext{
* Bu çalışma ikinci yazarın danışmanlığında birinci yazar tarafından hazırlanan yüksek lisans tezinden üretilmiștir.

** Milli Eğitim Bakanlığı, Niğde Milli Eğitim Müdürlüğü, Niğde, Türkiye, e-mail: nigdeli_kiraz_51@hotmail.com, ORCID: 0000-0001-6273-0496 iD

**** Erciyes Üniversitesi, Eğitim Fakültesi, Matematik ve Fen Bilimleri Eğitimi Bölümü, Kayseri, Türkiye, e-mail: cisik@erciyes.edu.tr, ORCID: 0000-0001-6326-0043
}

Kaynak Gösterme: Koç-Şanlı, K. \& Işıłk, C. (2020). Tam sayıların öğretim sürecinin öğretmenlerin model kullanımları üzerinden analizi. Bayburt Eğitim Fakültesi Dergisi, 15(29), 81-108. https://doi.org/10.35675/befdergi.519552 
Keywords: Mathematical modelling, model, integers, operations with integers.

\section{Giriş}

Eğitimin temel yapı taşlarından birisi olan matematik, bireylerin muhakeme yeteneklerini, düşünme becerilerini geliştiren en önemli çalışma alanlarından biridir (Işık \& Mercan, 2015). Matematik eğitimi ile bireylerin matematiksel kavramları ve sistemleri anlayarak bu kavram ve sistemleri gerçek hayatta ve diğer alanlarda kullanmaları beklenmektedir. Matematik eğitiminin amaçları arasında yer alan bireylerin gerçek yaşama hazırlanması geleneksel yöntemlerle yapılan eğitim ile mümkün değildir. Bunun için farklı yöntem ve tekniklerin kullanılması gerekmektedir. Matematik eğitiminde kullanılan modeller ile bireylerin gerçek yaşam problemlerine çözüm bulmaları amaçlanmaktadır. $\mathrm{Bu}$ bakımdan matematik eğitiminde modellerin kullanılması matematik eğitiminin amaçlarını gerçekleştirmek açısından önemlidir. 2013 yılında uygulamaya konulan, 2017 yılında revize edilen Ortaokul Matematik Dersi Öğretim Programı'nda [OMDÖP] da modellerin kullanılması önerilmiş, model ve modelleme öğrencilere kazandırılması gereken süreç becerileri arasında yer almıştır. Model kullanımı; öğrencilerin matematiğe yönelik olumlu tutum ve davranış geliştirmelerine yardımcı olması, matematiksel kavramların daha anlamlı olarak öğrenilmesine katkı sağlaması, gerçek yaşam ile matematik arasında ilişski kurulmasına imkân vermesi, bilgilerin zihinde tutulmasını kolaylaştırması, öğrencilerin iletişim becerilerini geliştirmesi ve matematik dilinin etkili bir şekilde kullanmasına yardımcı olması, öğrencilerin bilgiye ulaşmasını kolaylaştırması gibi nedenlerden dolayı önemli görülmektedir (Bayazit, Aksoy \& Kirnap, 2011).

Matematik eğitiminde kullanılan model ve modellemeler ile ilgili farklı araştırmacılar farklı farklı tanımlar yapmışlardır. Niss (1998), model kavramını "gerçek yaşam durumlarının temsili için matematiksel kavramlar ve bu kavramlar arasındaki ilişkiler üzerine kurulan bir sistem" olarak tanımlamaktadır. Matematik ile gerçek yaşam arasındaki çift yönlü geçiş sürecinde yer alan fiziksel ve bilişsel etkinlikleri ise modelleme olarak tanımlamaktadır (aktaran Bayazit, Aksoy \& Kırnap, 2011). Daupeto ve Porenti (1999) ise model kavramını, herhangi bir problemle alakalı gerçek bir durumun en sade şekilde temsil edilmesi olarak tanımlar ve modellerin problemi bazı yönlerden görselleştirerek, problemin özelliklerinin genellenerek kıyaslanması amacıyla kullanılabileceğini belirtir (aktaran Özgün, 2012). Görüldüğü gibi model ve modelleme birbirini tamamlayan kavramlardır. "Model ve modelleme arasındaki anlam farkı, ürün ve süreç arasındaki anlam farkına benzer" (Sriraman, 2005). Bu anlamda "modelleme" bir durumun soyut, sembolik veya fiziksel modelini oluşturma sürecini ifade ederken, "model” ise bu süreç sonunda oluşan ürünü ifade etmektedir. Matematiksel modellemenin, okul öncesinden yükseköğretime kadar olan tüm öğretim kademelerinde, kullanılmasına yönelik düşünceler son yıllarda daha fazla önem kazanmıştır. Matematiğin öğrenciler için daha anlamlı ve anlaşılır olarak gerçek yaşamla ilişkilendirerek öğrenmeleri gerektiği düşüncesi ve mevcut şartlardaki 
öğretimin bu hedefin gerçekleştirilmesinde yetersiz kalması, modellerin matematik eğitiminde kullanılması gerekliliği düşüncesinin temel kaynağı olmuştur.

Matematiksel modeller kavranmakta zorlanılan matematik konularının somutlaştırılmasında oldukça etkilidir. Soyut bir yapısı olan tam sayılar konusu da öğrencilerin başarısız olduğu ve zorlandıkları konuların başında gelmektedir. Araştırmalar tam sayıların özellikle negatif tam sayıların öğrenciler için zorluklar yarattığını göstermektedir, çünkü öğrenciler tam sayıları doğal sayılar hakkındaki varsayımlarına dayanarak oluşturmaya çalışırlar ve doğal sayılar için bildiklerinin tam sayılar için de geçerli olduğunu kabul ederler (Gallardo, 2002; Gallardo \& Romero, 1999; Peled, Mukhopadhyay \& Resnick, 1989). Erdem, Başıbüyük, Gökkurt, Şahin ve Soylu (2015), öğrencilerin en çok eksi (-) işaretini anlamlandırmada zorlandıklarını, bu sıkıntıyı gidermenin en etkili yolunun öğrencilerin negatif tam sayıların ya da eksi (-) işaretinin gerçek yaşamdaki karşılığını kavramsallaştırması olduğunu belirtmişlerdir. Araştırmacılar aynı araştırma sonucuna göre, öğrencilerin büyük bir çoğunluğunun sayının önündeki eksi işaretinin işlem mi yoksa yön mü belirttiği noktasında zorluk yaşadıklarını ifade edilmişlerdir. Bu zorluğun giderilmesi için de sayı doğrusu ya da sayma pullarının kullanılmasının etkili olacağı vurgulanmaktadır. Benzer şekilde Hativa ve Cohen (1995) öğrencilerin negatif tam sayıları karşılaştırmada zorluklar yaşadıklarını ve bu zorluğun üstesinden gelmek için sayı doğrusu modelinin etkili bir yöntem olduğu belirtilmektedir (Erdem, 2015; Fischbein, 1987; Hativa \& Cohen, 1995; Işıksal Bostan, 2009). Bozkurt ve Polat (2011) da tam sayılarla toplama ve çıkarma işleminde sayma pulları kullanımının anlaş1lır ve elverişli bir yöntem olduğunu belirtmişlerdir.

Tam sayı öğretiminde matematik eğitimcileri, birçok model önermiş ve kullanmışlardır. Günümüze kadar, pul, asansör, termometre, sıcak hava balonu, deniz seviyesi modeli, yönlü nesneler, borç alacak modelleri gibi modeller önerilmiştir (Crowley \& Dunn, 1985; English, 1997; Hativa \& Cohen, 1995; Liebeck, 1990; Mayer et al., 1995; Moreno \& Mayer, 1999). Bu modeller nicelik modeller ve yönlü modeller olarak literatüre kazandırılmıştır (Çetin, 2016). Öğrencilerin tam sayıları kavramalarına, tam sayıları karşılaştırmalarına ve tam sayılarda dört işlemi (toplama, çıkarma, çarpma ve bölme) yapabilmelerine yardımcı olmak için kullanılan ve birisi nicelik, diğeri de doğrusal işlemlere işaret eden iki model yaygındır. Bunlar: sayma pulları ve sayı doğrusu modelidir. Sayma pulları ve sayı doğrusundan başka tam sayılar konusunun kavratılmasında gerçek yaşam durumları modellemeleri de kullanılmaktadır. Ortaokul Matematik Dersi Öğretim Programı'nda (Milli Eğitim Bakanlığı [MEB], 2005, 2009, 2013a, 2017) sıcaklık, alacak-borç, kâr-zarar, gelirgider, yükseklik, zaman çizelgeleri, yön, hesap makineleri vb. gerçek yaşam durumlarının kullanılması istenmektedir. Pozitif ve negatif tam sayıların zıt yön ve değerleri ifade etmek için kullanıldığını öğrencilere kavratmak için asansördeki katlar, deniz seviyesinin altındaki ve üstündeki uzaklıklar, sıfırın altındaki ve üstündeki sıcaklıklar vb. modellerin kullanılabileceği belirtilmiştir. Mutlak değerin anlamı öğrencilere kavratılırken sayı doğrusu modeli ile asansör, termometre, banka 
hesabı vb. gibi gerçek yaşam durumları modellemelerinin, tam sayılarda karşılaştırma ve sıralama kazanımları için sayı doğrusu modelinin kullanılması gerektiği vurgulanarak, tam sayıların sıralanmasıyla ilgili gerçek yaşam durumlarını içeren modellerin kullanımı önerilmektedir. Tam sayılarda toplama ve çıkarma işleminde ise sayma pulları, termometre, asansör gibi araçlar ile dikey ve yatay sayı doğrusu modellerinin kullanılması önerilmektedir (MEB, 2018; s. 65). Tam sayılarla çarpma ve bölme işlemlerinde uygun modellerinin kullanılması istenmektedir.

Tam sayılar konusunun kavranmasına yardımcı olan, araştırmacılar ve Ortaokul Matematik Dersi Öğretim Programı (MEB, 2013a) tarafından kullanımları önerilen modellerin, öğretim sürecinin doğrudan merkezinde bulunan öğretmenler tarafindan öğretim ortamlarına yansımaları bilinmemektedir. Literatürde öğretmenlerin modelleme becerileri (Çiltaş \& Işık, 2013; Bayazit, Aksoy \& Kırnap, 2011; Frejd, 2012), modellerin öğretimdeki faydaları (Doruk \& Umay, 2011; Kal, 2013; Taghi Mosleh \& Jenaabadi, 2015), modelleme hakkındaki görüşleri (Bilen \& Çiltaş, 2015; Güder, 2013; Karalı, 2013; Korkmaz, 2010) ve modelleme ile ilgili farkındalıkları (Akgün, Çiltaş, Deniz, Çiftçi \& Işık, 2013) üzerine araştırmalarla karşılaşılmaktadır. Çelik ve Çiltaş (2015) ise, 5. Sınıf kesirler konusunun öğretim sürecini matematiksel modeller açısından incelemişlerdir. Buna karşın literatürde tam sayılar özelinde modellerin öğretmenler tarafindan ders ortamlarında kullanılıp kullanılmadığı, kullanılıyorsa ne düzeyde kullanıldığı ile ilgili bir araştırma ile karşılaşılmamıştır. Bu bağlamda araştırmada, tam sayılar ve tam sayılarla işlemler konularının öğretim sürecinin öğretmenlerin matematiksel model kullanımları ve model tercihleri üzerinden analiz edilmesi amaçlanmıştır. Bu amaç doğrultusunda aşağıdaki araştırma sorularına yanıt aranmıştır:

1) Ortaokul matematik öğretmenleri altıncı sınıf tam sayılar konusunun öğretim sürecinde matematiksel modelleri ne düzeyde kullanmaktadır?

2) Ortaokul matematik öğretmenleri altıncı sınıf tam sayılar konusunun öğretim sürecinde hangi matematiksel modelleri kullanmayı tercih etmektedirler?

3) Ortaokul matematik öğretmenleri yedinci sınıf tam sayılar konusunun öğretim sürecinde matematiksel modelleri ne düzeyde kullanmaktadır?

4) Ortaokul matematik öğretmenleri yedinci sınıf tam sayılar konusunun öğretim sürecinde hangi matematiksel modelleri kullanmayi tercih etmektedirler?

\section{Yöntem}

\section{Araştırma Deseni}

$\mathrm{Bu}$ araştırmanın konusu ve izlenilen süreç göz önüne alındığında, nitel araştırma yöntemlerinden olan durum (örnek olay) çalışmasının araştırma için en uygun desenin olduğuna karar verilmiştir. "Durum çalışmalarında bir durum derinliğine araştırılır ve 
bireyler, olaylar ve ortam gibi etkenlerin belirli bir durumu nasıl etkiledikleri ve etkilendikleri belirlenir" (Yıldırım \& Şimşek, 2013, s.83).

\section{Araştırma Grubu}

Araştırmanın çalışma grubunu 2016-2017 eğitim öğretim yılında Niğde'de görev yapan 5 matematik öğretmeni oluşturmaktadır. Nitel araştırmada kullanılan yöntem, teknik ve analizler düşünüldüğü zaman çalışma grubunun seçimini zaman, maliyet ve organizasyon etkilemektedir; bu yüzden çalışma grubu sınırlı tutulmalıdır. Yıldırım ve Şimşek'in (2013) de belirttiği gibi nitel araştırmalarda çalışma grubunun geniş olması her zaman mümkün değildir.

Öğretmenlerin ders gözlemleri video ile kayıt altına alındığı için öğretmenlerin seçiminde gönüllülük ilkesi dikkate alınarak çalışma grubu oluşturulmuştur. Bunun için de hem 6. Sınıf hem de 7. Sınıf düzeyinde matematik dersine giren öğretmenlerin seçimine özen gösterilmiştir. Çünkü çalışmanın yapıldığı tarih itibarıyla tam sayılarla toplama ve çıkarma işlemleri ile ilgili kazanımlar 6. Sınıf, tam sayılarla çarpma ve bölme işlemleri ile ilgili kazanımlar 7. Sınıfta yer almaktadır. Araştırmaya katılacak öğretmenlerle yüz yüze görüşülerek çalışmanın amacı, verilerin nasıl toplanacağı ve çalışmanın etik kuralları anlatılmış ve bu görüşmeler neticesinde de öğretmenin araştırmaya kendi rızası ile katılıp katılmayacağı sorularak çalışma grubu oluşturulmuştur. Araştırmanın çalışma grubunu oluşturan öğretmenlere Öğretmen 1 [Ö1], Öğretmen 2 [Ö2], Öğretmen 3 [Ö3], Öğretmen 4 [Ö4] ve Öğretmen 5 [Ö5] gibi kodlar verilmiştir. Çalışma grubunda yer alan öğretmenlerin hepsi Niğde il merkezindeki ortaokullarda görev yapan öğretmenlerdir. Çalışma grubunu oluşturan öğretmenler hakkında detaylı bilgi Tablo 1'de verilmiştir.

Tablo 1.

Çalışma Grubunu Oluşturan Öğretmenlerin Özellikleri

\begin{tabular}{|c|c|c|c|c|}
\hline & Cinsiyet & $\begin{array}{l}\text { Mesleki } \\
\text { Tecrübe }\end{array}$ & $\begin{array}{l}\text { Üniversitede Lisans } \\
\text { Eğitimi Sırasında } \\
\text { Matematiksel Modellerle } \\
\text { ile ilgili bir eğitim almış } \\
\text { mı? }\end{array}$ & $\begin{array}{l}\text { Seminer, Hizmet içi } \\
\text { eğitim vb. şekillerde } \\
\text { matematiksel } \\
\text { modellerle ilgili bir } \\
\text { eğitim almış mı? }\end{array}$ \\
\hline Ö1 & Kadın & $5 \mathrm{yll}$ & Evet & Hayır \\
\hline Ö2 & Erkek & $7 \mathrm{y} 11$ & Hayır & Hayır \\
\hline Ö3 & Erkek & $9 \mathrm{yll}$ & Evet & Hayır \\
\hline Ö4 & Kadın & 3 yil & Evet & Hayır \\
\hline Ö5 & Erkek & $10 \mathrm{y} 1 \mathrm{l}$ & Hayır & Hayır \\
\hline
\end{tabular}

\section{Veri Toplama Araçları}

“Genellikle durum çalışmalarında veri toplama aracı olarak görüşme, gözlem, arşiv kayıtları ve doküman incelemesi gibi bir dizi nitel veri toplama araçları; araştırmacının beklentilerine ve problemin doğasına uygun olarak tek başlarına veya 
birlikte kullanılabilirler" (Yıldırım \& Şimşek, 2013; s.188). Bu araştırmada da veri toplama aracı olarak gözlem (video kayıt cihazı, gözlem formu) kullanılmıştır. Gözlem yoluyla elde edilen veriler sonradan tekrar tekrar izlenebilmesi amaciyla video ile kaydedilmiştir. Gözlenen dersler modellerin kullanımı açısından araştırmacının hazırladığı yapılandırılmış gözlem formuyla değerlendirilmiştir. Her bir kazanım için gözlem formunda; (a) Kazanımlar işlenirken öğretmen tarafindan matematiksel modeller kullanıldı mı? (b) İşlenişte modeller dışında araç-gereç kullanıldı mı? (c) Öğrencilere soru (alıştırma) çözümlerinde model kullanıldı/kullandırıldı mı? (d) Problem çözümlerinde model kullanıldı/kullandırıldı mı? gibi sorulara cevap aranmıştır. Her bir kazanım için formda yer alan ifadelerin uygulanma durumuna göre "Evet", "Kısmen" veya "Hayır" seçeneklerinden biri işaretlenmiş̧tir. Eğer tam sayılar konusu anlatılırken hiçbir model kullanılmadıysa "Hayır", tam sayılar konusunda yer alan modellerden bir ya da iki tanesi kullanıldıysa "Kısmen”, eğer tüm modeller kullanılmışsa "Evet” seçeneği işaretlenmiş̧ir.

\section{Veri Toplama Süreci}

Araştırmada kullanılan gözlem formu kazanımlar bazında ele alınmış ve her bir kazanımın hangi tarihlerde ve kaç ders saatinde işlendiği not edilmiştir. Ortaokul Matematik Dersi Öğretim Programı'nda (MEB, 2013a), 6.sınıf tam sayılar konusunda 6 kazanım mevcuttur ancak bu kazanımlardan "toplama işleminin özelliklerini akıcı işlem yapmak için birer strateji olarak kullanır" kazanımı, araştırmanın amacı ile örtüşmediğinden çalışmanın dışında tutulmuştur. Gözlemlenerek video ile kayıt altına alınan kazanımlar için programın önerdiği süre 12 ders saati, yani yaklaşık olarak 2,5 haftalık bir süredir. 7.sınıf tam sayılar konusunda ise 3 kazanım mevcuttur ve bu kazanımlardan "tam sayılarla çarpma ve bölme işlemlerini yapar ve tam sayılarla işlemler yapmayı gerektiren problemleri çözer" kazanımları model kullanımını gerektirdiğinden bu kazanımların işlendiği dersler gözlenerek video ile kayıt altına alınmıştır. Tam sayılar konusundaki diğer kazanım olan "tam sayıların kendileri ile tekrarlı çarpımını üslü nicelik olarak ifade eder" kazanımı araştırmanın kapsamı dışında olduğu düşünüldüğünden çalışmanın dışında tutulmuştur. Gözlemlenerek video ile kayıt altına alınan kazanımlar için programın önerdiği süre 8 ders saati yani 1,5 haftalık bir süredir. Araştırmaya katılan öğretmenlerin bu kazanımları hangi tarihler arasında ve kaç ders saatinde işledikleri ile ilgili bilgiler aşağıdaki tabloda verilmiştir.

Tablo 2.

Tam Sayılar Konusundaki Kazanımların Öğretmenler Tarafindan Işslendikleri Tarihler ve Süreler

\begin{tabular}{clr}
\hline Öğretmenler & $\begin{array}{c}\text { Kazanımların } \\
\text { İşlendikleri Tarihler }\end{array}$ & $\begin{array}{c}\text { Kazanımların } \\
\text { İşlendikleri Süre }\end{array}$ \\
\hline Ö1 & $17.02 .2017-03.03 .2017$ & 12 ders saati \\
Ö2 & $24.02 .2017-09.03 .2017$ & 11 ders saati \\
Ö3 & $10.02 .2017-08.03 .2017$ & 18 ders saati
\end{tabular}




\begin{tabular}{lllr}
\cline { 1 - 1 } $\begin{array}{l}\text { 6. Sinıf } \\
\text { kazanımlar1 }\end{array}$ & Ö4 & $27.02 .2017-09.03 .2017$ & 8 ders saati \\
& Ö5 & $28.02 .2017-14.03 .2017$ & 11 ders saati \\
\hline \multirow{2}{*}{ 7. Sinıf } & Ö1 & $23.09 .2016-05.10 .2016$ & 10 ders saati \\
kazanımlar1 & Ö3 & $21.09 .2016-29.09 .2016$ & 5 ders saati \\
& Ö4 & $19.09 .2016-28.09 .2016$ & 6 ders saati \\
& Ö5 & $21.09 .2017-30.09 .2016$ & 6 ders saati \\
& $22.09 .2016-06.10 .2016$ & 10 ders saati \\
\hline
\end{tabular}

Tablo 2'ye bakıldığında, 6. Sınıf düzeyinde tam sayılar konusuyla ilgili kazanımları Ö4'ün en kısa sürede, Ö3'ün ise en uzun sürede işlediği görülmektedir. Ö4'ün tam sayılar konusunu işleme süresinin kısa olmasının nedeni, tam sayılarda toplama ve çıkarma işlemi ile ilgili problemleri çözer kazanımının derste işlenmemesidir. Ö3'ün tam sayılar konusunu işleme süresinin uzun olmasının nedeni ise tam sayılar konusu ile ilgili derste etkinlikler yapılmasıdır. Yine tablodan 7. sinıf düzeyinde yer alan kazanımların Ö2, Ö3 ve Ö4 tarafindan programda belirtilen süreden daha az Ö1 ve Ö5 tarafindan da programda belirtilen süreden daha fazla bir sürede işlendiği görülmektedir. Ö3'ün bu kazanımları işleme süresinin kısa olmasının nedeni programda yer alan hiçbir modellemeyi derste kullanmayıp sadece işlemler üzerinden konuyu tamamlamış olmasıdır. Ö2 ve Ö4'ün bu kazanımları işleme süresinin kısa olmasının nedeni ise "tam sayılarla işlemler yapmayı gerektiren problemleri çözer" kazanımının bu öğretmenler tarafından derste işlenmemiş olmasidır.

Derslerin video kamera ile kayıt altına alındığı sınıf ortamlarından da bahsetmek yerinde olacaktır. Dersleri gözlemlenen tüm öğretmenler Niğde il merkezindeki okullarda görev yapmaktadır. Ö4 hariç dersleri gözlenen diğer dört öğretmenin sınıflarında etkileşimli akıllı tahta mevcuttur. Sadece Ö4'ün sınıfinda beyaz tahta kullanılmaktadır. Ayrıca Ö4'ün sinıfında projeksiyon cihazı da yer almaktadır. Gözlem yapılan öğretmenlerin sınıfları en fazla 25 öğrenciden oluşmaktadır. Yalnızca Ö5'in sınıfındaki öğrenci sayısının biraz fazla olduğu (35 öğrenci) görülmüștür. Tüm öğretmenlerin sınıf ortamları diğer fiziksel özellikler açısından (temizlik, koku, aydınlanma vs.) benzerdir ve ders işlenmesine uygundur. Beş sınıfta da öğrencilerin dersten uzaklaşmalarına yol açacak ve dikkatini dağıtacak faktörler bulunmamaktadır. Yani sınıflarda fiziksel açıdan önemli farklılıklar söz konusu değildir.

Verilerin toplanması sürecinde araştırmacı, katılımcı olmayan gözlemci konumundadır. "Katılımcı olmayan gözlemci, araştırmaya dışarıdan bir yabancı olarak katılır, uzaktan izleme yoluyla gözlemlerini yapar" (Fraenkel, Wallen \& Hyun, 2012; Creswell, 2013). Katılımcı olmayan gözlemci, grup aktivitelerine katılmaz, kendini ortamdan soyutlayarak sürece müdahale etmez ve grubun bir üyesi olmaya çalışmaz (Bailey, 1994; Glesne, 1999). Bu yöntemin kullanıldığı araştırmalarda ortamın doğallığının korunması önemlidir. Bu doğrultuda araştırmada gözlem yapmaya başlamadan önce öğretmenler çalışılan konu ile ilgili yüzeysel olarak 
bilgilendirilmiş ancak araştırmaya ilişkin ayrıntılı bilgi verilmemiştir. Böylelikle öğretmenlerdeki davranış değişiklikleri önlenmeye çalışılmıştır. Yine bu sebeple gözlem yapılan sınıflardaki öğrencilerde sınıflarında gözlem yapıldığından haberdar edilmiş ancak konu ile ilgili bilgilendirilmemişlerdir. Çünkü araştırmanın amacı gereği, ortamın doğallığının dış etkenler nedeniyle bozulmaması önemlidir. Ders kayıtları sırasında sınıfların doğal ortamına hiçbir şekilde müdahale edilmemiştir. Hem doğal ortamın bozulmaması hem de araştırmacının beş öğretmeni aynı anda gözlemleyecek vakti olmadığından araştırmacı derslere katılmamıştır. Dersler kamera yardımıyla sınıfta yabancı biri olmadan kayıt altına alınmıştır. Bulgular yazılırken bu ders kayıtları ayrıntılı olarak tekrar tekrar izlenmiş ve doldurulan gözlem formundan da yararlanılarak değerlendirme yapılmıştır. Araştırmacının dışında bir uzman daha kayıtları izlemiş, değerlendirmiş ve gözlem formu doldurmuştur. Araştırmanın odak noktasında öğretmenlerin ders işleniş sürecinde model kullanımları yer almaktadır. Araştırmacı dışındaki uzman da izlediği görüntüleri yapılandırılmış gözlem formuna aktarmada sorun yaşamamış ve araştırmacı ile fikir ayrılığına düşmemişsir. Dolayısıyla gözlem formlarının oluşturulmasında araştırmacı ve uzman arasında tam uyum sağlanmıştır. Ders kayıtlarından alınan görüntülere araştırmanın bulgular kısmında yer verilerek anlatılmak istenen durumun daha net anlatılması ve anlaşılması hedeflenmiştir.

Doğası gereği nitel araştırmaların geçerlik ve güvenirliklerini nicel araştırmalardaki gibi sayısal verilerle belirlemek kolay değildir. $\mathrm{Bu}$ nedenle araştırmanın geçerliliği için veri toplama araçlarında çeşitliliğe gidilmiş̧ir (sınıf gözlemleri yanında öğretim sürecinde model kullanma ve modeller konusunda öğretmenlerle de görüşmeler yapılmıştır). Bunun yanı sıra iki uzmanın görüşleri alınmış, uzun süreli veri kayıtları gerçekleştirilmiş ve gözlemlerin analizinde tamamen Ortaokul Matematik Ders Programı'ndaki kazanımlarla birlikte programın önerdiği modellere odaklanılmıştır. Güvenirlik boyutunda ise araştırmanın bütün aşamaları, başka araştırmalar için tekrarlanabilir olması açısından detaylı bir şekilde açıklanmaya çalışılmıştır. Gözlem ve görüşmelerden elde edilen ham veriler sonradan incelenebilmesi için saklanmıştır.

\section{Verilerin Analizi}

$\mathrm{Bu}$ çalışmada gözlem yoluyla elde edilen veriler analiz edilirken betimsel analiz yöntemi kullanılmıştır. "Betimsel analizde gözlenen ya da görüşülen bireylerin görüşlerini ve mevcut durumlarını çarpıcı bir biçimde yansıtmak için doğrudan alıntılara sık sık yer verilir. Veriler önce açık ve sistematik bir biçimde betimlenir, daha sonra yapılan betimlemeler açıklanarak yorumlanır, son olarak neden sonuç ilişkileri incelenerek bir takım çıkarımlara ulaşılır”. Yıldırım ve Şimşek'e (2013, s.224) göre betimsel analiz 4 aşamada incelenmektedir.

1. Betimsel analiz için çerçeve oluşturmast: Araştırmanın kavramsal yapısı ve görüşmelerde yer alan boyutlar göz önüne alınarak genel bir taslak yapı oluşturulur. 
Eğer bu yapı önceden oluşturulmamış ise temaların oluşturulması oldukça zor olacaktır.

2. Tematik çerçeveye göre verilerin işlenmesi: Bir önceki aşamada oluşturulan çerçeveye göre verilerin düzenlenmesi yapılır, organize edilir ve yorumlanır. Burada önemli olan şey verilerin mantıklı bir şekilde organize edilmesidir.

3. Bulguların tanımlanmast: Organize edilen veriler tanımlanarak doğrudan alıntılarla güçlendirilir.

4. Bulguların yorumlanmast: Tanımlanan bulguların anlamlandırılması ve ilişkilendirilmesi bu aşamada yapılır. Bulgular arasındaki örüntülerin ortaya koyulması ve farklı olgularla kıyaslanarak nedenselliğinin açıklanması ön plandadır. Bu durum araştırmacının daha nitelikli yorumlar yapmasına imkân verir.

$\mathrm{Bu}$ aşamalara uygun olarak gözlem sonuçları analiz edilirken önce bir çerçeve oluşturulmuş ve verilerin kazanım bazında değerlendirilmesi yapılmıştır. Sonrasında ise ders kayıtları tekrar tekrar izlenerek ve gözlem formundan da yararlanılarak yazılı döküm hazırlanmıştır. Bu dökümler için matematik eğitiminde uzman kişilerin de fikri alınmıştır. Ders anlatımları tam sayılar konusunda matematik öğretim programında yer alan modellere göre analiz edilmiştir. Derslerde kullanılan modeller analiz edilirken bu alanla ilgili kuramsal çerçeve göz önüne alınarak derslerdeki ilgili kesitler verilmiştir. Kazanımların beş öğretmen tarafından nasıl işlendiği, tam sayılar konusunda programda yer alan modelleri kullanıp kullanmadıkları, eğer kullandılarsa hangi modelleri kullandıkları ayrıntılı bir şekilde anlatılarak yorumlanmıştır.

\section{Bulgular ve Yorum}

\section{Öğretmenlerin Altıncı Sınıf Tam Sayılar Konusunun Öğretim Sürecinde Matematiksel Modelleri Kullanım Düzeylerine Yönelik Bulgular}

$\mathrm{Bu}$ başlık altında 6. sınıfta yer alan tam sayılar konusundaki her bir kazanımın öğretmenler tarafından anlatılırken modellerin ne düzeyde kullanıldığı ve hangi modellerin sıklıkla kullanılıp hangi modellerin kullanımının tercih edilmediğinden bahsedilmiştir.

Kazanım 1: Tam sayıları yorumlar ve sayı doğrusunda gösterir (OMDÖP, 2013, s.14).

Öğretmenlerin bu kazanımı işlerken kullandıkları modeller aşağıdaki tabloda gösterilmiştir. 
Tablo 3.

Tam Sayıları Yorumlar ve Sayı Doğrusunda Gösterir Kazanımına Yönelik Model Kullanım Analizi

\begin{tabular}{lccccc}
\hline Model Çeşitleri & Ö1 & Ö2 & Ö3 & Ö4 & Ö5 \\
Sayı doğrusu & $\mathrm{X}$ & $\mathrm{X}$ & $\mathrm{X}$ & $\mathrm{X}$ & $\mathrm{X}$ \\
Gerçek yaşam durumları & $\mathrm{X}$ & $\mathrm{X}$ & $\mathrm{X}$ & $\mathrm{X}$ & $\mathrm{X}$ \\
\hline
\end{tabular}

Tablo 3'e bakıldığında, bu kazanım işlenirken programda yer alan modellerin tüm öğretmenler tarafindan kullanılmış olduğu görülmektedir. Gözlemlenen öğretmenler içerisinden sadece Ö3’ün tam sayıların yönlü sayılar olduğu üzerinde durduğu ve tam sayıların gerçek yaşam durumları ile ifade edilmesine yönelik etkinliklere yer verdiği görülmüştür. Tüm öğretmenler bu kazanımı programda belirtilen süreden daha az zamanda bitirmişlerdir. Aşağıda Ö3'ün tam sayıları tanıtırken kullanmış olduğu sayı doğrusu modeli ve tam sayıların yönlü sayılar olduklarına dair yazdırmış olduğu nota ait alıntı verilmiştir.
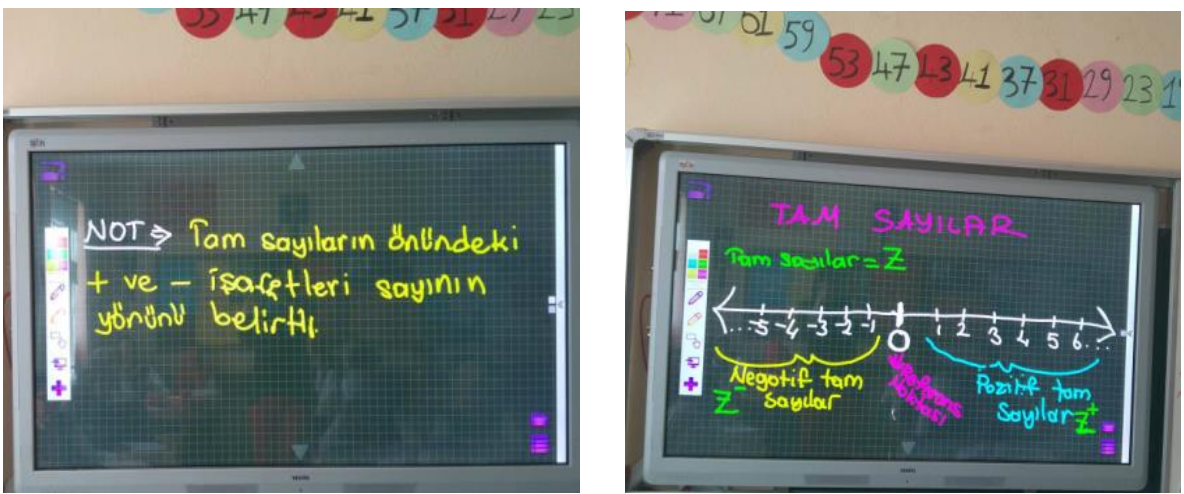

Şekil 1. Ö3'ün tam sayıları tanıtırken kullanmış olduğu sayı doğrusu modeli ve tam sayıların yönlü sayılar olduğuna dair yazdırmış olduğu not.

Kazanım 2: Bir tam sayının mutlak değerini belirler ve anlamlandırır (OMDÖP, 2013, s.14).

Öğretmenlerin bu kazanımı işlerken kullandıkları modeller aşağıdaki tabloda gösterilmiştir.

Tablo 4.

Bir Tam Sayının Mutlak Değerini Belirler ve Anlamlandır Kazanımına Yönelik Model Kullanım Analizi

\begin{tabular}{lccccc}
\hline Model Çeşitleri & Ö1 & Ö2 & Ö3 & Ö4 & Ö5 \\
\hline Sayı doğrusu & & $\mathrm{X}$ & $\mathrm{X}$ & $\mathrm{X}$ & $\mathrm{X}$ \\
Gerçek yaşam durumları & $\mathrm{X}$ & $\mathrm{X}$ & $\mathrm{X}$ & \\
\hline
\end{tabular}

Tablo 4 incelendiğinde, Ö1 dışında tüm öğretmenlerin sayı doğrusu modelini kullandığı görülmektedir. Ö1 dışında tüm öğretmenler mutlak değerin anlamını sayı 
doğrusu modelini kullanarak öğrencilere açıklamış, fakat yalnızca Ö3 soru çözümlerinde de sayı doğrusu modelini kullanmıştır. Gerçek yaşam durumlarının ise Ö2, Ö3 ve Ö4 tarafindan kullanıldığ1 görülmektedir. Ö3, derste sorulan sorularda gerçek yaşam durumlarına yer vermiştir. Mutlak değeri anlatırken Ö2 ve Ö4'ünde benzetim modellerini yani gerçek yaşam durumlarını kullandıkları gözlenmiştir. Tüm öğretmenler kazanımı programda belirtilen süreden daha az bir zamanda işlemişlerdir. Ö2 ve Ö4' ün mutlak değer kavramını anlatırken kulanmış oldukları benzetimlere ait alıntılar aşağıda verilmiştir.
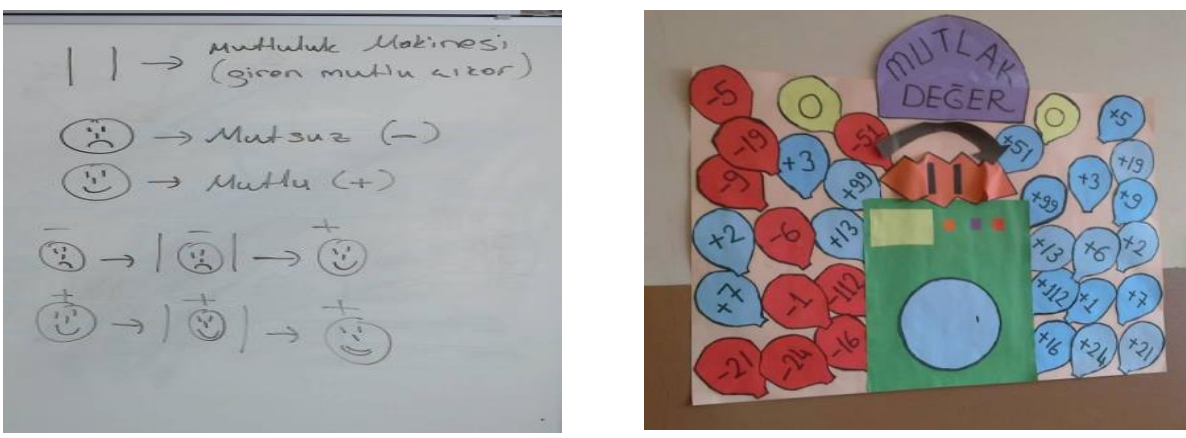

Şekil 2. Ö2'nin ve Ö4'ün mutlak değerle ilgili benzetimlerine ait görüntüler.

Kazanım 3: Tam sayıları karşılaştırır ve sıralar (OMDÖP, 2013, s.14).

Öğretmenlerin bu kazanımı işlerken kullandıkları modeller Tablo 4.3'te gösterilmiştir.

Tablo 5.

Tam Sayıları Karşılaştırır ve Stralar Kazanıma Yönelik Model Kullanım Analizi

\begin{tabular}{|c|c|c|c|c|c|}
\hline Model Çeşitleri & Ö1 & Ö2 & Ö3 & Ö4 & Ö5 \\
\hline Sayı doğrusu & & $\mathrm{X}$ & $\mathrm{X}$ & & $\mathrm{X}$ \\
\hline Gerçek yaşam durumları & & & $X$ & $\mathrm{X}$ & \\
\hline
\end{tabular}

Tablo 5'e bakıldığında, tam sayıları karşılaştırır ve sıralar kazanımı işlenirken Ö1 ve Ö4 dışındaki öğretmenlerin sayı doğrusu modelini kullandıkları görülmektedir. Gerçek yaşam durumları modellemelerinin ise sadece Ö3 ve Ö4 tarafindan kullanıldığı gözlenmiştir. Ö1, kazanımın işlenişi sırasında sayı doğrusu modelini kullanmamış fakat soru çözümlerinde sayı doğrusu modelinden yararlanmıştır. Bunun yanı sıra Ö5'in sıralama konusunda sayı doğrusu modeli ile birlikte tekerleme ve benzetimden faydalandığı gözlenmiştir. Ö5, tam sayıların karşılaştırılmasını öğrencilerine kavratmak için ilk önce tahtaya sağa doğru gidildikçe sayıların büyüdüğü sola doğru gidildikçe ise sayıların küçüldüğü bir sayı doğrusu çizdi. Çizimini bitirdikten sonra ise sayı doğrusu üzerinde sağa doğru gidildikçe sayıların büyüyeceğini ve sola doğru gidildikçe ise sayıların küçüleceğini vurguladı. Gönüllü bir öğrenciyi tahtaya kaldırarak sayı doğrusunda sağa doğru ilerlemesini, ilerlerken de "büyüdüm, büyüdüm, büyüdüm” ifadelerini her adımda tekrarlamasını istedi. Daha 
sonra ise öğrencinin sola doğru ilerlemesini, ilerlerken de "küçüldüm, küçüldüm, küçüldüm" ifadelerini her adımda tekrarlamasını istedi. Aşağıdaki görselde Ö5' in tahtaya çizmiş olduğu sayı doğrusu modeline ait alıntı verilmiştir.

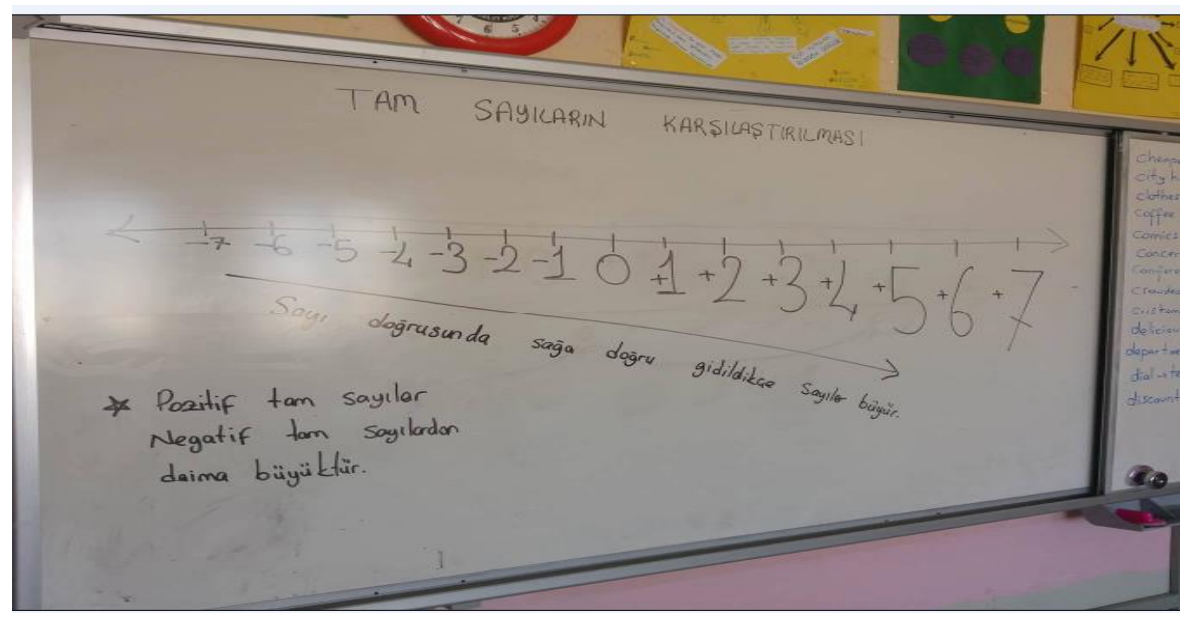

Şekil 3. Tam sayıları karşılaştırır ve sıralar kazanımının Ö5 tarafından derste işlenişi.

Kazanım 4 ve 5: Tam sayllarla toplama ve çıkarma işlemlerini yapar; ilgili problemleri çözer ve tam sayılarda çıkarma işleminin eksilenin ters işaretlisi ile toplamak anlamına geldiğini kavrar (OMDÖP, 2013, s.14).

Öğretmenlerin bu kazanımı işlerken kullandıkları modeller aşağıdaki tablolarda gösterilmiştir.

Tablo 6.

Tam Sayılarla Toplama İşlemi Konusunda Model Kullanım Analizi

\begin{tabular}{lccccc}
\hline Model Çeşitleri & Ö1 & Ö2 & Ö3 & Ö4 & Ö5 \\
\hline Sayma pulları & $\mathrm{X}$ & $\mathrm{X}$ & $\mathrm{X}$ & $\mathrm{X}$ & $\mathrm{X}$ \\
Sayı doğrusu & $\mathrm{X}$ & $\mathrm{X}$ & $\mathrm{X}$ & & \\
Gerçek yaşam durumları & & & & $\mathrm{X}$ & \\
\hline
\end{tabular}

Tablo 6'ya bakıldığında, tam sayılarda toplama işlemi işlenirken tüm öğretmenlerin sayma pulları ile modellemeleri kullandığı görülmektedir. Öğretmenler tarafindan en az kullanılan modelin ise gerçek yaşam durumları modellemeleri olduğu görülmektedir.

Tablo 7.

Tam Sayılarla Çıkarma İşlemi Konusunda Model Kullanım Analizi

\begin{tabular}{lccccc}
\hline Model Çeşitleri & Ö1 & Ö2 & Ö3 & Ö4 & Ö5 \\
\hline Sayma pulları & $\mathrm{X}$ & $\mathrm{X}$ & $\mathrm{X}$ & $\mathrm{X}$ & $\mathrm{X}$ \\
Sayı doğrusu & & $\mathrm{X}$ & $\mathrm{X}$ & & \\
Gerçek yaşam durumları & & & & $\mathrm{X}$ & \\
\hline
\end{tabular}


Tam sayılarda çıkarma işlemi işlenirken de, tam sayılarda toplama işleminde olduğu gibi tüm öğretmenlerin sayma pulları ile modellemeleri kullandığı görülmektedir. Yine en az kullanılan model gerçek yaşam durumları modelleri olmuştur. Tam sayılarla çıkarma işleminde sayı doğrusu modelinin kullanımında toplama işlemine göre bir azalma olmuştur. Ö1, öğrencilerine toplama işleminin sayı doğrusu üzerinde modellenmesini göstermiş fakat çıkarma işleminin sayı doğrusu üzerinde modellenmesini göstermemiştir. Tam sayılarla toplama ve çıkarma işlemi işlenirken en çok kullanılan model sayma pulları modeli olmuştur. Aşağıda Ö4'ün bu konuyu işlerken kullanmış olduğu sayma pulları modeliyle ilgili dersten yapılan alıntılar verilmiştir.
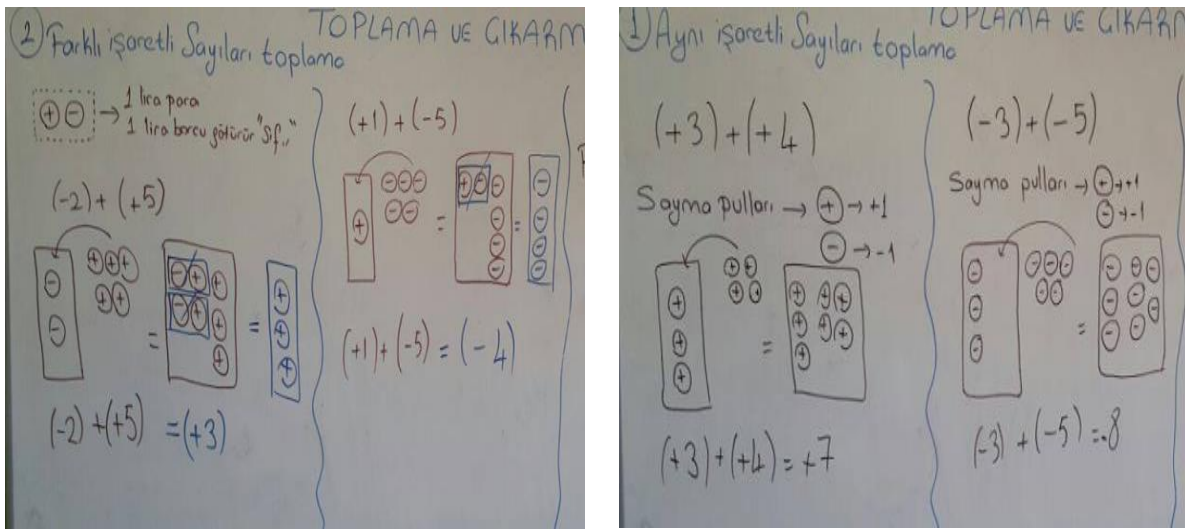

Şekil 4. Tam sayılarda toplama işleminin sayma pulları ile modellenmesi (Ö4).

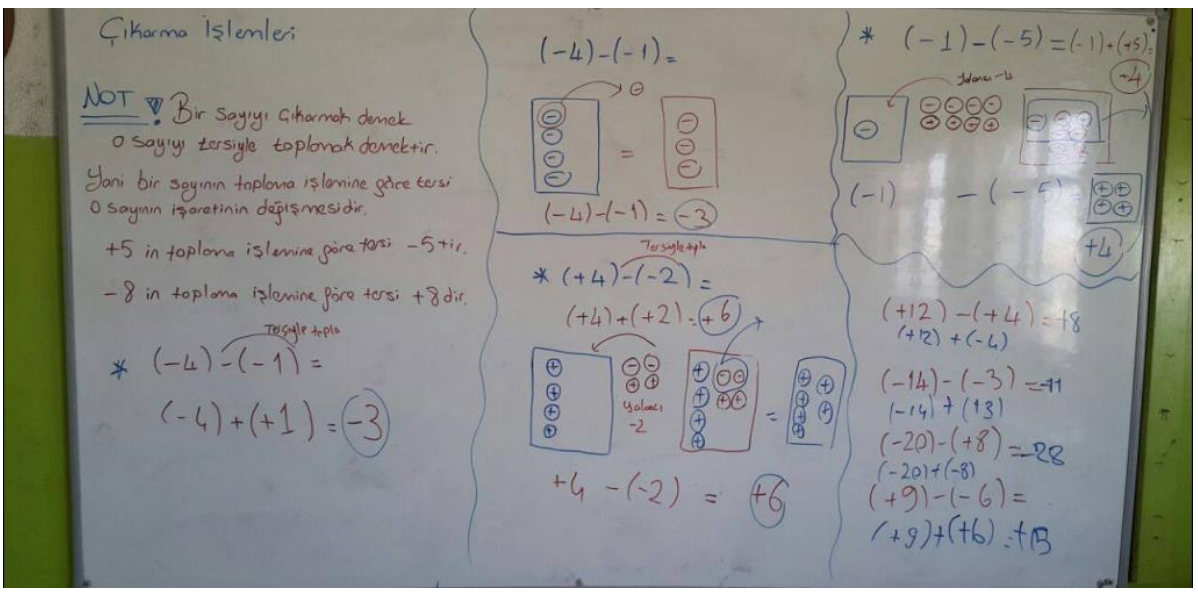

Şekil 5. Tam sayılarda çıkarma işleminin sayma pulları ile modellenmesi (Ö4).

Ö3, derste göstermiş olduğu sayma pulları ile modellemelerin daha iyi anlaşılması için renkli fon kartonları yardımıyla hazırlanan sayma pulları ile öğrencilerin 
uygulama yapmalarını sağlamıştır. Bir ders saati sürecince yapılan bu uygulama ile öğrenciler hem eğlenmiş hem de öğrenmişlerdir. Derste yapılan bu uygulamaya ait alıntı aşağıda verilmiştir.
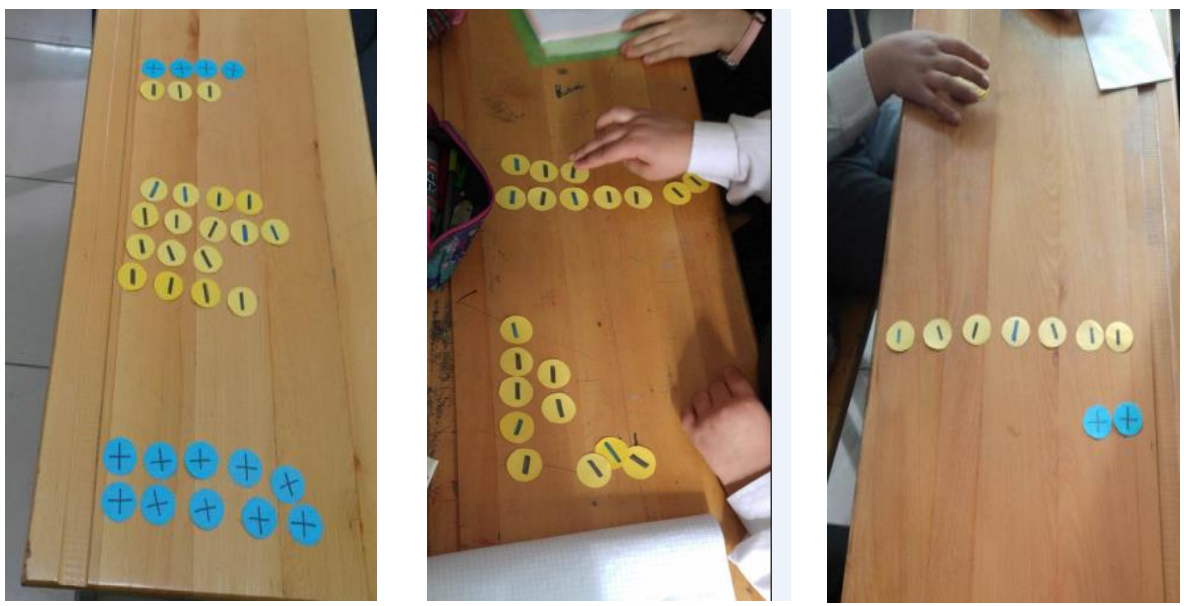

Şekil 6. Renkli fon kartonlarıyla yapılan sayma pullarının derste kullanıldığı etkinlik

(Ö3).

Ö3 ayrıca sayı doğrusu modeli ile tam sayılarla toplama ve çıkarma işlemlerinin de daha iyi anlaşılması için sınıfta bu konuyla ilgili bir etkinlik yaptı. Sınıftaki fayanslara sayı doğrusunda olduğu gibi tam sayılar yerleştirildi. Daha sonra öğrenciler referans noktasına geçerek istenilen hareketleri yaptılar. Derste kendisine $(+2)+(-5)$ işlemi verilen öğrenci önce referans noktasından 2 adım sağa gitti daha sonra gelmiş olduğu noktadan 5 adım sola giderek işlemin sonucuna ulaştı. Derste yapılan bu etkinlik sırasında öğrencilerin oldukça eğlenmiş oldukları görüldü. Şekil 7’de bu etkinlik sırasında çekilmiş olan fotoğraflar yer almaktadır. 

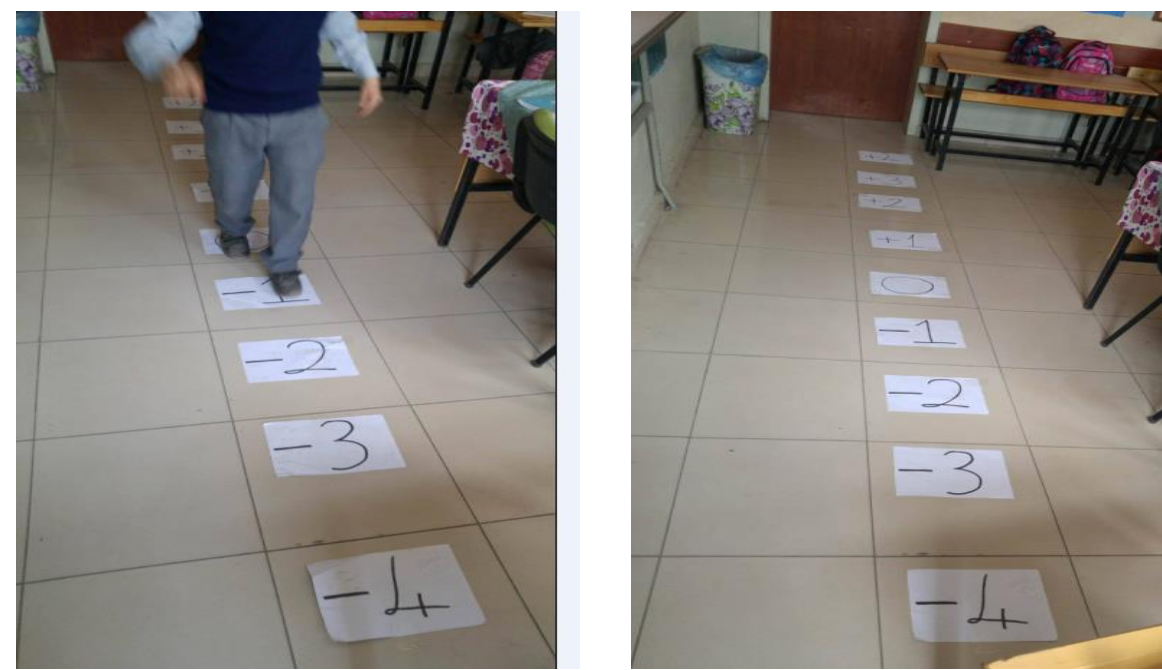

Şekil 7. Sayı doğrusu modelinin derste kullanıldığı etkinlik (Ö3).
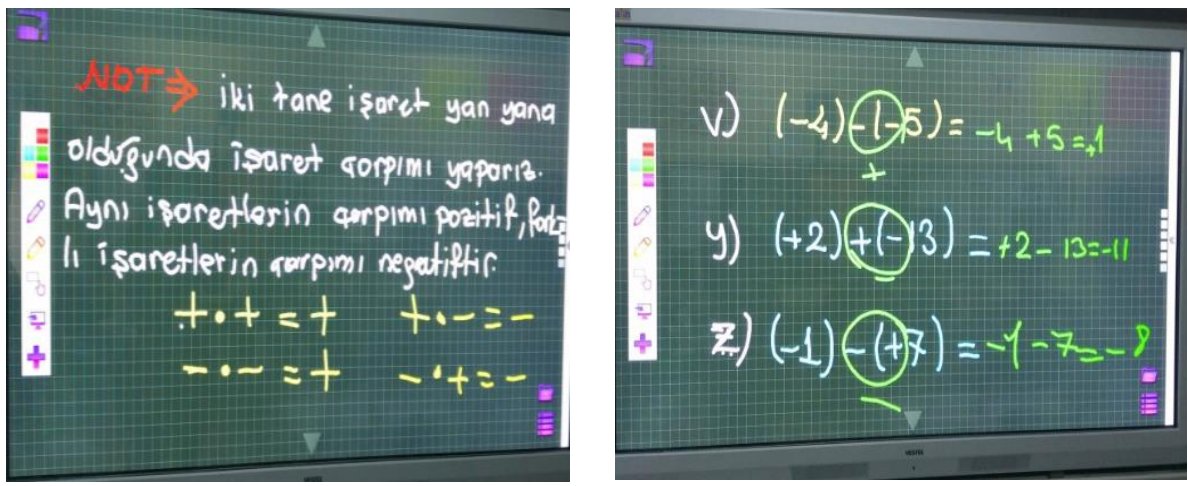

Şekil 8. Ö3'ün öğrencilere gösterdiği işaret çarpımı ve uygulamaları.

Tam sayılarla toplama ve çıkarma işlemi kazanımları işlenirken, bazı öğretmenlerin (Ö1, Ö3 ve Ö4) 7. sınıfta gösterilmesi gereken işaret çarpımını öğrencilere gösterdikleri gözlenmiştir (Şekil 8). Öğrencilerden bu işaret çarpımını kullanarak tam sayılarda toplama ve çıkarma işlemlerini yapmalarını istemişlerdir. Şekil 8 'de bahsedilen bu durumla ilgili alıntılara yer verilmiştir.

"Tam sayılarla toplama ve çıkarma işlemlerini yapar; ilgili problemleri çözer ve tam sayılarda çıkarma işleminin eksilenin ters işaretlisi ile toplamak anlamına geldiğini kavrar" kazanımlarına programda 5 ders saati kadar bir süre ayrılmıştır. Tüm öğretmeler bu kazanımları programda belirtilen süreden daha fazla sürede işlemişlerdir. Tam sayılarla ilgili diğer kazanımları programda belirtilen süreden daha az bir sürede işleyen öğretmenler, tam sayılarla işlemlere programda verilen süreden daha fazla bir süre ayırmışlardır. 


\section{Öğretmenlerin Yedinci Sınıf Tam Sayılar Konusunun Öğretim Sürecinde Matematiksel Modelleri Kullanım Düzeylerine Yönelik Bulgular}

$\mathrm{Bu}$ başlık altında 7. sınıfta yer alan tam sayılar konusundaki her bir kazanımın öğretmenler tarafindan işlenirken modellerin ne düzeyde kullanıldığı ve hangi modellerin sıklıkla kullanılıp hangi modellerin kullanılmasının tercih edilmediğinden bahsedilmiştir.

Kazanım 1: Tam sayılarla çarpma ve bölme işlemlerini yapar (OMDÖP, 2013, s.25).

Öğretmenlerin bu kazanımı işlerken kullandıkları modeller aşağıdaki tabloda gösterilmiş̧ir.

Tablo 8

Tam Sayılarla Carpma İslemi Konusunda Model Kullanım Analizi

\begin{tabular}{lccccc}
\hline Model Çeşitleri & Ö1 & Ö2 & Ö3 & Ö4 & Ö5 \\
\hline Sayma pulları & $\mathrm{X}$ & $\mathrm{X}$ & & $\mathrm{X}$ & $\mathrm{X}$ \\
Sayı doğrusu & & & & & \\
Gerçek yaşam durumları & & & & & $\mathrm{X}$ \\
\hline
\end{tabular}

Tablo 8 incelendiğinde, öğretmenlerin tam sayılarla çarpma işleminin öğretiminde en çok kullandıkları modelin sayma pulları modeli olduğu söylenebilir. Ö3 dışında tüm öğretmenler derste sayma pulları ile modellemeyi kullanmışlardır. Ö1 dışındaki diğer öğretmenler ders işlenişi esnasında sayma pulları ile modellemeyi göstermiş fakat öğrencilere bu model ile ilgili soru çözümü yaptırmamışlardır. Sadece Ö1, öğrencilere bu modellerle ilgili uygulama yapma imkânı vermiştir. Sayma pulları ile modellemeyi kullanan öğretmenlerde gözlemlenen dikkat çekici bir başka durum ise şu olmuştur: tüm öğretmenler işlemlerin modellenmesini göstermiş fakat hiçbir öğretmen verilen modellemeye karşıllk gelen işlemi bulma etkinliklerine yer vermemiştir. Aşağıda sayma pulları modeliyle ilgili Ö4'ün dersinden yapılan alıntı verilmiştir. 


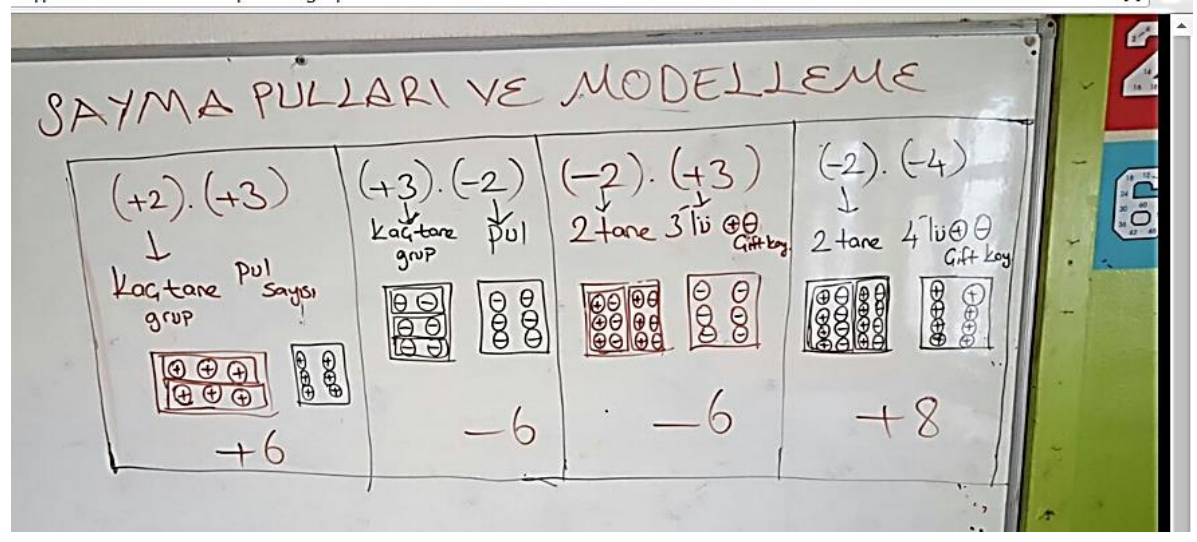

Şekil 9. Ö4 tarafindan çarpma işleminin sayma pulları ile modellenmesine ait görüntü.

Tablo 8'e bakıldığında hiçbir öğretmenin sayı doğrusu modelini kullanmadığı da görülmektedir. Gerçek yaşam durumları ise sadece Ö5 tarafindan kullanılmıştır. Ö4 ve Ö5 öğrencilere işaret çarpımını anlatırken kural olarak vermek yerine benzetimlerden yararlanmayı tercih etmişlerdir. Ö4, işaret çarpımı ve bölümünün öğrencilere öğretirken aynı düşüncedeki insanların yan yana geldiğinde olumlu sonuçların olacağını farklı düşüncedeki insanların ise bir araya geldiklerinde olumsuz sonuçların olacağına yönelik bir benzetimden yararlandı. Öğretmenin kullandığı bu benzetimin öğrencilerin işaret çarpımı ve bölümünü daha kolay öğrenmelerini sağladığı gözlendi. Gerçekten de derste yapılan soru çözümlerinde öğrencilerin hiç birinin işaret çarpımı ve bölümünde sorun yaşamadığı görüldü. Aşağıda Ö4'ün anlatmış olduğu işaret çarpımına ait benzetimin görüntüsü verilmiştir.

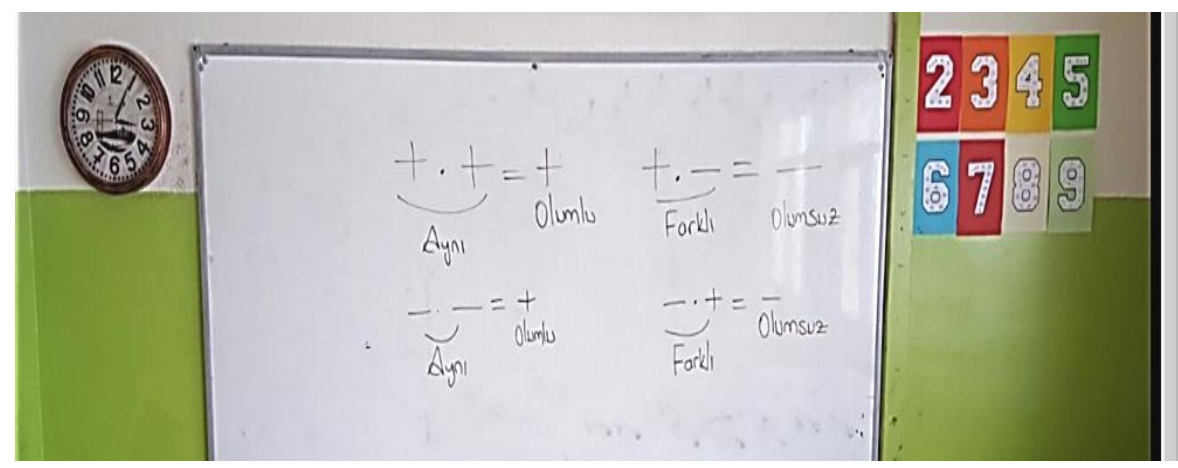

Şekil 10. Ö4'ün anlattığg işaret çarpımına ait benzetimin görüntüsü

Ö5, İşaret çarpımı ve bölümünü öğrencilere dost-düşman benzetmesini kullanarak gösterdi. "+” işaretlerin dost “_“" işaretlerinin ise düşman olduğunu söyledi. "+..+ = 
+" işaret çarpımını "dostumun dostu, dostumdur" ya da “-.+ = -" işaret çarpımını “düşmanımın dostu, düşmanımdır” şeklinde ifade etti.

Tablo 9.

Tam Sayllarla Bölme Isşlemi Konusunda Model Kullanım Analizi

\begin{tabular}{lccccc}
\hline Model Çeşitleri & Ö1 & Ö2 & Ö3 & Ö4 & Ö5 \\
\hline Sayma pulları & $\mathrm{X}$ & & & & $\mathrm{X}$ \\
Sayı doğrusu & & & & & \\
Gerçek yaşam durumları & & & & & \\
\hline
\end{tabular}

Tablo 9 incelendiğinde, öğretmenlerin tam sayılarla bölme işleminde model kullanmayı çok fazla tercih etmedikleri söylenebilir. Sadece Ö1 ve Ö5 derslerinde sayma pulları ile modellemeye yer vermişlerdir. Ö1, öğrencilere modelle ilgili uygulama yapma imkânı sunarken, Ö5 sadece konu işlenirken modelleri kullanmış öğrencilere modellerle ilgili uygulama yaptırmamıştır. Sayma pulları ile ilgili modellemeye derslerinde değinen Ö1 ve Ö5'in her ikisi de işlemin modellenmesini göstermişler ancak verilen modele karşılık gelen işlemin yazılmasını öğrencilerden istememişlerdir. Tablo 9'a bakıldığında sayı doğrusu ve gerçek yaşam durumları modellerinin öğretmenler tarafından kullanılmadığı görülmektedir. Ö5'in tam sayılarla bölme işlemini sayma pulları ile modellenmesine ait dersten yapılan alıntı aşağıda verilmiştir.

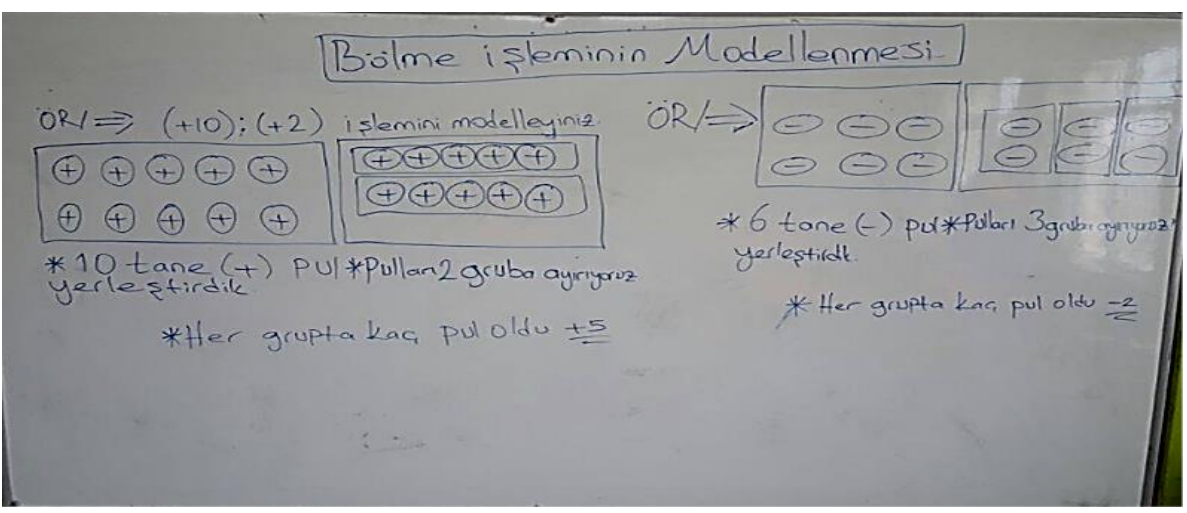

Şekil 11. Bölme işlemini sayma pulları ile modellenmesi (Ö5).

Kazanım 2: Tam sayılarla işlemler yapmayı gerektiren problemleri çözer (OMDÖP, 2013, s.25).

Tam sayılarla işlemler yapmayı gerektiren problemleri çözer kazanımına yönelik gözlem yapılan öğretmenlerin problem durumlarını oluştururken gerçek yaşam durumlarını kullandıkları gözlenmiştir. Ö2 ve Ö4 tarafindan bu kazanım işlenmediğinden onlar bu değerlendirmenin dışında tutulmuştur. Öğretmenler gerçek yaşam durumlarından farklı örnekler kullanarak problem durumlarını 
oluşturmuşlardır. Fakat Ö3 dişında diğer öğretmenler problem durumların çözümlerinde model kullanmamış, problemleri işlemler yaparak çözmeyi tercih etmişlerdir. Ö3 ise, problemleri çözerken de modellere başvurmuş, bu durumunda çözülen problemlerin anlaşılırlığını kolaylaştırdığı gözlenmiştir. Ö3’ün modelleri kullanarak problemleri çözmeye çalıştığı durumlara ait dersten yapılan alıntılar aşağıda verilmiştir.
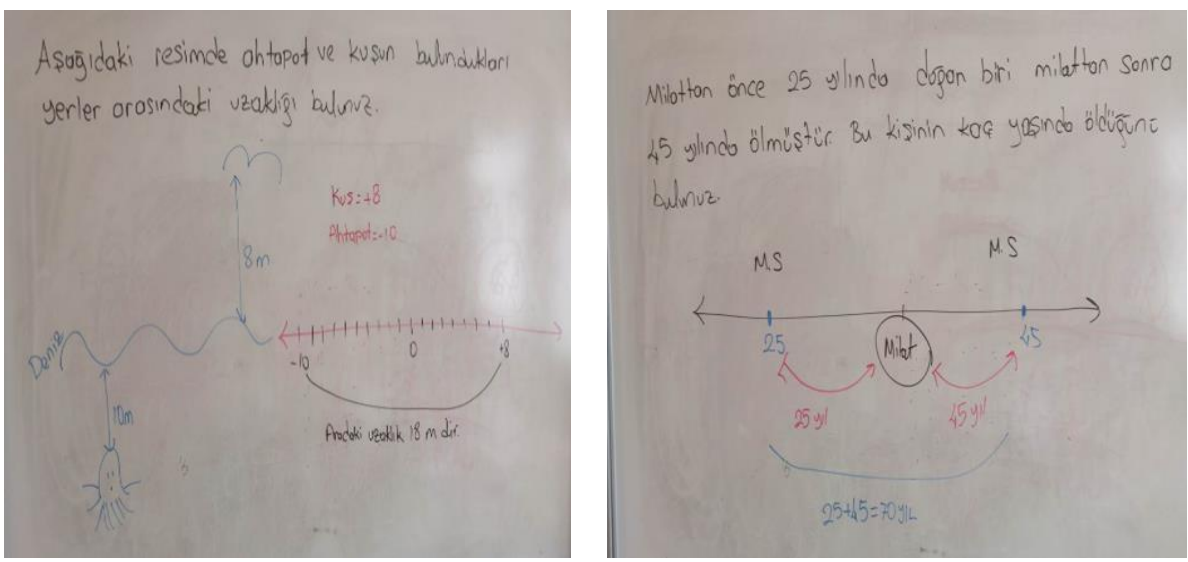

Şekil 12. Ö3'ün dersinde kullandığı problem durumları ve çözümleri.

\section{Tartışma, Sonuç ve Öneriler}

Çalışmada tam sayılar ve tam sayılarla işlemler konularının öğretim sürecinde, öğretmenlerin model kullanımları ve model tercihlerinin doğal sınıf ortamına yansımaları analiz edilmeye çalışılmıştır. Öğretmenlerin tam sayılar ve tam sayılarla işlemlere yönelik ders işleniş süreçlerine ait video kayıtlarının analizlerinden, modellerin öğretmenler tarafından düzenli olarak kullanılmadığı gözlenmiştir. Çalışma grubunu oluşturan öğretmenler, bazı kazanımların öğretim sürecinde model kullanmayı tercih ederlerken bazı kazanımlarda ise model kullanmaktan kaçınmışlardır. Bunun yanı sıra öğretmenler tam sayılarla ilgili programda önerilen modellerin tamamını da kullanmamışlardır. Araştırmada ulaşılan öğretmenlerin derste düzenli olarak model kullanmayı tercih etmemeleri sonucu, Çelik (2015) ile Akgün, Çiltaş, Deniz, Çiftçi ve Işık'ın (2013) çalışmalarından elde edilen sonuçlarla uyum içerisindedir. Çelik (2015), öğretmenlerin modelleri faydalı bulmalarına rağmen düzenli olarak kullanmadıkları, benzer şekilde Akgün, Çiltaş, Deniz, Çiftçi ve Işık (2013) da öğretmenlerin matematiksel modelleri derslerinde yeterince kullanmadıkları sonucuna ulaşmışlardır.

Öğretmenlerin tam sayılar konusunun 6. sınıf düzeyindeki kazanımlarında 7. sınıfta yer alan kazanımlara oranla model kullanmayı daha çok tercih ettikleri gözlenmiştir. Öğretmenler en çok "tam saylları yorumlar ve sayı doğrusunda gösterir" kazanımını işlerken model kullanmışlardır. Bu kazanım ile ilgili tam sayılar 
konusunda yer alan gerçek yaşam durumları ve sayı doğrusu modeli beş öğretmenin tamamı tarafindan kullanılmıştır. Öğretmenlerin en az model kullandıkları kazanım ise 7.sinıf düzeyinde yer alan "tam sayllarla çarpma ve bölme işlemini yapar" kazanımı olmuştur. Bu kazanım işlenirken tam sayılarla bölme işleminin öğretim sürecinde, gerçek yaşam durumları ve sayı doğrusu modeli hiçbir öğretmen tarafindan kullanılmazken, sayma pulları modeli sadece iki öğretmen tarafindan (Ö1 ve Ö5) kullanılmıştır. Benzer şekilde, tam sayılarla çarpma işleminin öğretim sürecinde ise sayı doğrusu modeli yine hiçbir öğretmen tarafindan kullanılmazken, gerçek yaşam durumlarına ait modeller sadece bir öğretmen (Ö5) tarafindan kullanılmışırı. Ulaşılan bu sonuç Bozkurt ve Polat'ın (2011) yapmış oldukları çalışmadan elde ettikleri sonuç ile örtüşmektedir. Bozkurt ve Polat (2011), tam saylarla toplama ve çıkarma işlemlerinin modellenmesi sürecinde öğretmenlerin sayma pullarını kullandıkları sonucuna ulaşmışlardır. Buna karşın öğretmenler, sayma pullarını tam sayılarla çarpma ve bölme işlemlerini modellemede zorluk yaşadıkları gerekçesiyle çok fazla tercih etmedikleri sonucuna ulaşmışlardır.

Öğretmenlerin derste kullanmayı tercih ettikleri modeller benzerlik göstermektedir. Dersleri gözlenen öğretmenlerin en az kullandıkları modelin gerçek yaşam durumları olduğu görülmüştür. Oysa literatürde (Altun, 2008; Erdem, 2015; Işıksal Bostan, 2009; MEB, 2009, 2013a; Van De Walle, Karp, \& Bay Williams, 2010) tam sayıların gerçek yaşamla ilişkilendirilmesinin etkili öğrenmeler sağlayacağı vurgulanmaktadır. Sayma sayıları gerçek nesnelerle ifade ederek zihinde somutlaştırabilirken negatif sayılarla yapılan işlemler ancak matematiğin mantığıyla anlam kazanabilmektedir. Bu mantığı ögrencilere en iyi şekilde verebilmek için de öğrencileri sürece dahil etmek, konuyu günlük hayatla bağdaştırmak oldukça önemlidir (Akyazı \& Kaplan, 2018). Çalışma grubundaki öğretmenler tam sayıları öğrenciye kavratırken, karşılaştırırken ve mutlak değer kavramını öğretirken en çok sayı doğrusu modelini kullanmışlardır. Birçok araştırmacı tarafindan da sayı hissini oluşturmak için sayı doğrusu modelinin kullanılmasının kaçınılmaz olduğu vurgulanmıştır (Hiebert \& Carpenter, 1992, Lakoff \& Nunez, 2000). Sayı doğrusu modeli, sayıların düzlem üzerindeki konumlarına ve hareketlerine yönelik (Kilhamn, 2011; Nurnberger Haag, 2007) düşünülebilir. Bu çalışmada, tam sayılarla işlemler konusunda ise öğretmenlerin en çok kullandıkları modelin sayma pulları modeli olduğu gözlenmiştir. Bozkurt ve Polat da (2011) tam sayılarla toplama ve çıkarma işleminde sayma pulları kullanımının anlaşılır ve elverişli bir yöntem olduğunu belirtmişlerdir. Sayma pulu modelleri bir nesne olarak öğrencilerin önceki pozitif sayı bilgilerini kullanmaya yardım eder. Örneğin, öğrenciler doğal sayılarla çıkarmayı ilk kez öğrendiklerinde yaptıkları gibi negatif sayılarla çıkarmayı nesnelerin uzaklaştırılması olarak düşünebilirler (French, 2001; Liebeck, 1990).

Öğretmenlerin sınıf düzeyine ve konulara göre model kullanımlarının farklılık gösterdiği de ulaşılan bir diğer sonuçtur. 6. sınıf konularının öğretim sürecinde en çok model kullanan öğretmenin Ö3 olduğu görülmüsşür. Buna karşın Ö3, 7. sınıfta yer alan kazanımları işlerken hiçbir model kullanmamıştır. 7. sınıf kazanımlarının işleniş 
sürecinde ise modellerden en çok faydalanan öğretmenin ise Ö5 olduğu gözlenmiştir. Çalışma grubundaki öğretmenlerin ders gözlemlerinden, modellerin daha çok konuların giriş düzeyinde kavramsal bilginin oluşum sürecinde kullanıldığ 1 görülmüştür. Öğretmenler soru çözümlerinde çok fazla model kullanmamışlardır. Bu nedenle öğrenciler modelle ilgili çok fazla uygulama yapma imkânı bulamamışlardır. Araştırmadan elde edilen bu sonuç Çelik'in (2015) ulaştığı sonuç ile benzerlik taşımaktadır. Çelik (2015) yapmış olduğu araştırma sonucunda, öğretmenlerin modelleri daha çok konuyu anlatırken kullandıkları, soru çözümlerinde model kullanımını çok fazla tercih etmedikleri sonucuna ulaşmıştır. $\mathrm{Bu}$ sonuç ile bu araştırmadan elde edilen sonuç paralellik göstermektedir.

Dersleri video ile kayıt altına alınan öğretmenlerin video kayıtlarının analizinden, ders süresince öğretmenlerin ders kitaplarını hiç kullanmadıkları belirlenmiş̧ir. Öğretmenler gerek konu anlatımlarında, gerekse soru çözümlerinde ders kitabını hiç kullanmamışlar, dolayısıyla ders kitabında yer alan modellerden faydalanmamışlardır. Tam sayılar konusunu işlerken model kullanan öğretmenlerin seçtikleri modellerin ders kitabından bağımsız olduğu gözlenmiştir. Ders kitabında tam sayılarla ilgili yer alan model türlerinin hepsini öğrencilerine göstermeyen öğretmenler, kullandıkları model örneklerinde de ders kitabından yararlanmamışlardır. Bu sonuç Güder (2013) tarafından yapılan çalışmanın sonuçlarıyla farklılaşmaktadır. Güder (2013) yaptığı çalışma sonucunda öğretmenlerin vermiş oldukları model örneklerinin ders kitabındaki örneklerle benzer olduğu sonucuna ulaşmıştı. Ders kitapları, öğrenme öğretme etkinliklerine doğrudan yön verebilmeleri açısından öğrenci ve öğretmenler için çok önemli bir yere sahiptir (Ar Yavuz, 2007).

Çalışa grubunda yer alan öğretmenlerin ders gözlemlerinin analizinden ders işlenişleri sırasında sınırlı sayıda ve türde model kullandıkları görülmüştür. Buna karşın 2017 yllında revize edilen Matematik Dersi Öğretim Programı'nda, matematiksel modelleme matematiğe özgü beceriler arsında yer alan matematiksel süreç becerileri içerisinde özellikle vurgulanmaktadır. Chan, Ng, Widjaja ve Seto'nun (2015) da belirttiği gibi, öğretmenler modelleme sürecine aşina olmalıdır ve modelleme süreciyle ilgili tecrübe sahibi olmalıdırlar. Bu bağlamda öğretmenlerin matematiksel modellere yönelik bilgilerini geliştirmek ve matematiksel modellemeye yönelik tutumlarını arttırmak amacıyla hizmet içi eğitimler düzenlenebilir. Bunun yanında ortaokullarda seçmeli ders olan matematik uygulamaları derslerinde matematiksel model ve modelleme etkinliklerine yer verilebilir. Böylece model ve modellemeye ayrılan zaman artabilecek, öğrencilerin matematiği daha anlamlı ve günlük yaşamla ilişkilendirerek öğrenmelerinin önü açılmış olacak ve programda vurgulanan matematiksel modelleme becerisinin kazanımına hizmet edilmiş olunacaktır. Ayrıca adında uygulama kelimesini barındıran "matematik uygulamaları" derslerinde öğrencilerin ve öğretmenlerin model geliştirmeleri ve geliştirdikleri modeller üzerinde çalışmaları da faydalı olacaktır. Her ne kadar bu araştırmanın doğrudan bir alt problemi olmasa da, ders kitaplarının öğretim sürecinde 
öğretmenler tarafindan kullanılmaması dikkat çekicidir. Ders kitapları tam sayılar özelinde modeller açısından incelendiğinde, kullanılan modellerin nicelik ve tür açısından çeşitlilik göstermediği belirlenmiştir. Bunun yanında bölüm sonu alıştırma ve uygulamalar kısmında da modellerle ilgili sorulara yer verilmediği görülmektedir. Bu bağlamda sınıf içi ve sınıf dışı öğrenme sürecinin temel elemanlarından birisi olan ders kitapları özelde tam sayılar, genelde ise bütün konularda model ve modelleme bağlamında daha zengin bir içeriğe sahip olacak şekilde düzenlenebilir. Ders kitabındaki alıştırmalar ve uygulamalar kısmında yer alan sorular da öğrencileri model kullanmaya ve matematiksel model oluşturmaya teşvik edecek şekilde düzenlenebilir.

Çalışmanın 5 matematik öğretmeni ile yürütülmesi ve tam sayılar ve tam sayılarla işlemler konusunun 6. ve 7. sınıf düzeyinde yer alması çalışmanın bir sınırlılığı olarak düşünülebilir. Ancak çalışma deseninin gözleme dayalı nitel kategoride oluşu göz önüne alındığında çalışma grubu anlamlı olacaktır. Bunun yanında çalışma yürütüldüğü zaman itibarıyla tam sayılar ve tam sayılarla işlemler Ortaokul Matematik Dersi Öğretim Programı'nda 6 sınıf ve 7. sinıfta yer almaktaydı. Revize edilen 2017 yılı programı ile birlikte tam sayılar ve tam sayılarla işlemler 7. sınıf düzeyine kaydııılmıştır. Buna karşın kazanımlarda ve modelleme ile ilgili vurgularda bir değişiklik olmamışıtır. Dolayısıyla güncellik ve sınırlılık tehdidi ortadan kalkmıştır. Literatür incelendiğinde, model ve modelleme ile ilgili farklı araştırmalar (modellerin öğrenci başarısına etkisi, öğretmenlerin modellerle ilgili görüşleri, modellerin matematik tutumuna etkisi, öğretmen ve öğrencilerin model oluşturma etkinlikleri vb.) yapılmış olmasına rağmen, öğretmenlerin modelleri öğretim sürecinde kullanımlarını inceleyen araştırma sayısı yok denecek kadar azdır. Özellikle matematiksel modelleme becerisi ortaokul matematik programına girmişken ve Ortaöğretim Matematik Dersi (9, 10, 11 ve 12. sınıflar) Öğretim Programı'nda (MEB, 2013b) da matematiksel yeterlilik ve beceriler arasında yer alırken, öğrencilerin farklı öğrenme alanlarındaki alt öğrenme alanlarına yönelik modelleme ve model kullanma becerileri de araştırılabilir. Benzer şekilde öğretmenlerin derslerdeki model kullanma ve modelleme süreçleri de farklı sınıf düzeyi ve farklı ögrenme alanları üzerinden de araştırilabilir.

\section{Çıkar Çatışması ve Etik Bildirimi}

Yazarlar arasında çıkar çatı̧ması bulunmadı̆̆ını ve tüm araştırmacıların çalı̧maya katkı sunduğunu beyan etmiş̧ir. Yazarlar tüm etik kurallara uyduklarını bildirmiştir.

\section{Kaynakça}

Akgün, L., Çiltaş, A., Deniz, D., Çiftçi, Z., \& Işık, A. (2013). İlköğretim matematik öğretmenlerinin matematiksel modelleme ile ilgili farkındalıkları. Adiyaman Üniversitesi Sosyal Bilimler Enstitüsü Dergisi, 6(12), 1-34. 
Akyazı, N., \& Kaplan, A. (2018). Drama yöntemi ile tam sayılarla toplama işleminin öğretimi: 6. sınıf öğrencilerinden yansımalar. Bayburt Eğitim Fakültesi Dergisi, 13(25), 259-294.

Altun, M. (2008). Illköğretim ikinci kademe (6, 7 ve 8. sinıflarda) matematik ögrretimi (5. Baskı). Bursa: Aktüel Yayıncılık.

Ar Yavuz, G. (2007). Illköğretimde kullanılan ders kitaplarının öğretime yardımcı unsurlar açısından değerlendirilmesi (Yayımlanmamış yüksek lisans tezi). Gazi Üniversitesi Eğitim Bilimleri Enstitüsü, Ankara.

Bailey, K. D. (1994). Methods of social research (4. Edt.). New York: The Free Press.

Bayazit, İ., Aksoy, Y., \& Kırnap, S. M. (2011). Öğretmenlerin matematiksel modelleri anlama ve model oluşturma yeterlilikleri. e-journal of New World Sciences Academy, 6(4), $1 \mathrm{C} 0456$.

Bilen, N., \& Çiltaş, A. (2015). Ortaokul matematik dersi beşinci sınıf öğretim programının Öğretmen görüşlerine göre model ve modelleme açısından incelenmesi. Kafkas Üniversitesi, e-Kafkas Eğitim Araştırmaları Dergisi, 2(2), 40-54.

Bozkurt, A., \& Polat, M. (2011). Sayma pullarıyla modellemenin tam sayılar konusunu öğrenmeye etkisi üzerine öğretmen görüşleri. Gaziantep Üniversitesi Sosyal Bilimler Dergisi, 10(2), 787-801.

Chan, E. C., Ng, D. K., Widjaja, W., \& Seto, C. (2015). A case study on developing a teacher's capacity in mathematical modelling. The Mathematics Educator, 16(1), $1-31$.

Creswell, J. (2013). Research design (fourth edition). Thousand Oaks, CA: Sage

Crowley, M. L., \& Dunn, K. A. (1985). On multiplying negative numbers. Mathematics Teacher, 78(4), 252-256.

Çelik, B. (2015). Beşinci sınıf kesirler konusunun öğretim sürecinin matematiksel modeller açısından incelenmesi (Yayımlanmamış yüksek lisans tezi). Atatürk Üniversitesi, Eğitim Bilimleri Enstitüsü, Erzurum.

Çelik, B., \& Çiltaş, A. (2015). Beşinci sınıf kesirler konusunun öğretim sürecinin matematiksel modeller açısından incelenmesi. Bayburt Eğitim Fakültesi Dergisi, 10(1), 180-204.

Çetin, H. (2016). Sorgulayıcı öğrenme yaklaşımıyla çoklu temsil destekli tam sayı ögretiminin 6. sinıf ögrencilerinin başarllarına model tercihlerine ve temsiller arası geçiş becerilerine etkisi (Yayımlanmamış doktora tezi). Necmettin Erbakan Üniversitesi, Eğitim Bilimleri Enstitüsü, Konya. 
Çiltaş, A., \& Işık, A. (2013). Matematiksel modelleme yoluyla öğretimin ilköğretim matematik öğretmeni adaylarının modelleme becerileri üzerine etkisi. Kuram ve Uygulamada Eğitim Bilimleri, 13(2), 1177-1194.

Doruk, B. K., \& Umay, A. (2011) Matematiği günlük yasama transfer etmede matematiksel modellemenin etkisi. Hacettepe Üniversitesi Eğitim Fakültesi Dergisi (H. U. Journal of Education) 41, 124-135.

Erdem, E. (2015). Zenginleştirilmiş öğrenme ortamının matematiksel muhakemeye ve tutuma etkisi (Yayımlanmamış doktora tezi). Atatürk Üniversitesi, Eğitim Bilimleri Enstitüsü, Erzurum.

Erdem, E., Gökkurt, B., Şahin, Ö., Başıüyük, K., \& Soylu, Y. (2015). Examining prospective middle school mathematics teachers' modelling skills of multiplication and division in fractions. Croatian Journal of Education, 17(1), 11-36.

Fischbein, E. (1987). Intuition in science and mathematics: An educational approach. Reidel, Dordecht, The Netherlands.

Fraenkel, J. R., Wallen, N. E., \& Hyun, H. H. (2012). Internal validity. How to design and evaluate research in education. New York: McGraw-Hill.

French, D. (2001). Two minuses make a plus. Mathematics in School, 30(4), 32-33.

Frejd, P. (2012). Teachers' conceptions of mathematical modelling at Swedish upper secondary school. Journal of Mathematical Modelling and Application, 1(5), 1740 .

Gallardo, A. (2002). The extension of the natural-number domain to the integers in the transition from arithmetic to algebra. Educational Studies in Mathematics, 49(2), 171-192.

Gallardo, A., \& Romero, M. (1999). Identification of difficulties in addition and subtraction of integers in the number line. F. Hitt, M. Santos (Eds.), Proceedings of the Twenty-first International Conference for the Psychology of Mathematics Education (Vol. I, pp. 275-282). North American Chapter, Mexico.

Glesne, C. (1999). Becoming qualitative researchers. New York: Longman.

Güder, Y. (2013). Ortaokul matematik öğretmenlerinin matematiksel modellemeye ilişkin görüşleri (Yayımlanmamış yüksek lisans tezi). Fırat Üniversitesi, Eğitim Bilimleri Enstitüsü, Elazığ.

Hativa, N., \& Cohen, D. (1995). Self learning of negative number concepts by lower division elementary students through solving computer-provided numerical problems. Educational Studies in Mathematics, 28(2), 401-431.

Hiebert, J., \& Carpenter, T. P. (1992). Learning and teaching with understanding. In D. A. Grouws (Ed.), Handbook of research on mathematics teaching and learning (pp. 65-97). NewYork: Macmillan. 
Işık, A., \& Mercan, E. (2015). Ortaokul matematik öğretmenlerinin model ve modelleme hakkındaki görüşlerinin incelenmesi. K. Ü. Kastamonu Eğitim Dergisi 23 (4), 1835-1850.

Işıksal Bostan, M. (2009). Negatif sayılara ilişkin zorluklar, kavram yanılgıları ve bu yanılgıların giderilmesine yönelik öneriler. E. Bingölbali ve M. F. Özmantar (Ed.), Illkögretimde karşılaşılan matematiksel zorluklar ve çözüm önerileri içinde (s. 155-184). Ankara: Pegem Akademi Yayınları.

Kal, F. M. (2013). Matematiksel modelleme etkinliklerinin ilköğretim 6.sınıf ögrencilerinin matematik problemi çözme tutumlarına etkisi (Yayımlanmamış yüksek lisans tezi). Kocaeli Üniversitesi, Fen Bilimleri Enstitüsü, Kocaeli.

Kilhamn, C. (2011). Making sense of negative numbers (Unpublished doctoral dissertation). University of Gotenburg, Faculty of Education, Sweden. Retrieved from https://gupea.ub.gu.se/handle/2077/24151?locale=en

Korkmaz, E. (2010). Ilköğretim matematik ve sınıf ögretmeni adaylarının matematiksel modellemeye yönelik görüşleri ve matematiksel modelleme yeterlikleri (Yayımlanmamış doktora tezi). Balıkesir Üniversitesi, Fen Bilimleri Enstitüsü, Balıkesir.

Lakoff, G., \& Nunez, R. E. (2000). Where mathematics comes from: How the embodied mind brings mathematics into being. New York: Basic Books.

Liebeck, P. (1990). Scores and forfeits-an intuitive model for integer arithmetic. Educational Studies in Mathematics, 21, 221-239.

Milli Eğitim Bakanlığı. (2005). İlköğretim matematik dersi 6-8. sinıflar ögrretim programı. Talim ve Terbiye Kurulu Başkanlığı, Ankara.

Milli Eğitim Bakanlığı. (2009). Illköğretim matematik dersi 6-8. sinıflar öğretim programı. Talim ve Terbiye Kurulu Başkanlığı, Ankara.

Milli Eğitim Bakanlığı. (2013a). Ortaokul matematik dersi (5, 6, 7 ve 8. sinıflar) ögretim programı. Talim ve Terbiye Kurulu Başkanlığı, Ankara.

Milli Eğitim Bakanlığı. (2017). Ortaokul matematik dersi (5, 6, 7 ve 8. sinıflar) ögretim programı. Talim ve Terbiye Kurulu Başkanlığı, Ankara.

Milli Eğitim Bakanlığı. (2013b). Ortaöğretim matematik dersi (9, 10, 11 ve 12. sınıflar) ögretim programı. Talim ve Terbiye Kurulu Başkanlığı, Ankara.

Niss, M. (1998). Aspects of the nature and state of research in mathematics education. Educational Studies in Mathematics 40, 1-24.

Nurnberger Haag, J. (2007). Integers made easy: Just walk it off. Mathematics Teaching in the Middle School, 13(2), 118-121. 
Özgün, D. (2012). İlköğretim matematik öğretmen adaylarının problem çözme sürecinde ürettiği matematik modellerinin nitel bir yaklaşımla incelenmesi (Yayımlanmamış yüksek lisans tezi). Erciyes Üniversitesi, Eğitim Bilimleri Enstitüsü, Kayseri.

Peled, I., Mukhopadhyay, S., \& Resnick, L. B. (1989). Formal and informal sources of mental models for negative numbers. In Proceedings of the 13th international conference for the Psychology of Mathematics Education (Vol. 3, pp. 106-110). Paris, France.

Sriraman, B. (2005). Conceptualizing the notion of model eliciting. fourth congress of the european society for research in mathematics education. Sant Feliu de Guíxols, Spain.

Taghi Mosleh. O., \& Jenaabadi, H. (2015). The impact and role of modeling on learning and achievements in mathematics among junior high schools of Iranshahr. Applied Psychology, 11, 42-49.

Van De Walle, J., Karp, K. S., \& Bay Williams, J. M. (2010). Elementary and middle school mathematics; Teaching developmentally (7th Ed.). Boston, MA: Allyn \& Bacon.

Yıldırım, A., \& Şimşek, H. (2013). Sosyal bilimlerde nitel araştırma yöntemleri (Genişletilmiş 9. baskı). Ankara: Seçkin Yayıncılık.

\section{Extended Abstract}

With the help of models used in mathematics education, it is aimed for individuals to solve real life problems. In this respect, using models in mathematics education is significant for accomplishing the aims of mathematics education. Middle School Mathematics Curriculum has been in use since 2013 and revised in 2017. Usage of models is suggested in this curriculums, besides models and modeling played a part as a process skill that students should gain.

Integers as an abstract topic is the most struggling one for students and students are generally not successful. Researches indicated that students specifically had difficulties with negative integers because students try to understand integers with their assumptions about natural numbers and they accept what they know about natural numbers are also right for integers (Gallardo, 2002; Gallardo \& Romero, 1999; Peled, Mukhopadhyay \& Resnick, 1989). Similarly, Hativa and Cohen (1995) indicated that students had difficulties with negative integers and to overcome this difficulty they suggested using number line model as a method (Erdem, 2015; Fischbein, 1987; Hativa \& Cohen, 1995; Işıksal Bostan, 2009; NCTM, 1989). Bozkurt and Polat (2011) stated that using number flakes was an understandable and convenient method with addition and subtraction operations. 
Teachers, who are in center of instructional process, do not know how to reflect models to instructional environment although usage of models is suggested both by researchers and in Middle School Mathematics Curriculum (2013a). Although in current literature there are various studies like teachers' modeling skills (Bayazıt, Aksoy \& Kırnap, 2011; Çiltaş \& Iş1k, 2013; Frejd, 2012), the advantages of models in teaching process (Doruk \& Umay, 2011; Kal, 2013; Taghi Mosleh \& Jenaabadi, 2015) and teachers' opinions about modeling (Bilen \& Çiltaş, 2015; Güder, 2013; Karal1, 2013; Korkmaz, 2010), there is not a study about if teachers used models in teaching integers in their instructional process, if they use models what its usage level is. In this study, it was aimed to analyze teachers' usage and preference of mathematical models at their teaching of integers and operations with integers.

In this study, case study approach, which is a qualitative research method, is used. Participants of the study were composed 5 middle school mathematics teachers working in Niğde Province during 2016-2017 academic year. Lesson observations were videotaped therefore, in selection of teachers' willingness to participate this study was considered primarily. Face to face meetings were done with participant teachers. Aim of the study, how data would be collected, and ethical issues regarding this study were explained to participants. At the end of these meetings, teachers were asked if they wanted to participate this study voluntarily or not, as a result sample of this study was determined. Participant teachers were coded as Teacher 1 [T1], Teacher 2 [T2], Teacher 3 [T3], Teacher 4 [T4] and Teacher 5 [T5].

Data gathering tool of this study was observation (video recording device, observation form). For watching data gathered many times, observations were also videotaped. Lessons observed were evaluated with observation form for analyzing with regard to usage of models. In this study structured observation form was used. In the observation form, it was tried to answer while teaching related objectives if teachers used models or not, if teachers used models which models they preferred, if teacher gave chance their students to use these models or not. While video recordings, researcher did not interfere natural classroom settings. Both for not interfering natural classroom setting and for the impossibility of observing 5 teachers at the same time, the researcher did not attend classrooms. With the advent of cameras, no stranger attended these lessons but the lessons were videotaped.

After collecting data through observations, data gathered were analyzed with descriptive analysis method. While analysis of data related with observations, a framework was formed and data gathered were evaluated based on related objectives. Then, video recordings were watched again and again and with the help of observation forms written documents were prepared. For these written documents, opinions of experts in mathematics education were taken. Instructional processes about integers were analyzed with regard to models in mathematics curriculum.

In analysis of videos about instructional processes of teachers' teaching integers and operations in integers, it was observed that models were not used regularly by teachers. Participant teachers preferred using models for some objectives and did not 
use models for other objectives. Moreover, teachers did not use all the models suggested in the mathematics curriculum. It was observed that teachers preferred using more models in their instructional processes for 6th objectives than 7th grade objectives. Models preferred by teachers for their instructional processes were similar. Least model used by teachers observed was real life situations. In fact, in current literature (Altun, 2008; Erdem, 2015; Işıksal Bostan, 2009; MEB, 2009 \& 2013; Van de Walle et al.,2010) it was emphasized that relating integers with real life situations would result in effective learning. Participants in this study generally used number line models for students to comprehend integers, to compare integers, and to learn absolute value. 